\title{
secretion system
}

3

\section{Mohammed Kaplan $^{1}$, Catherine M Oikonomou ${ }^{1}$, Cecily R. Wood ${ }^{2}$, Georges Chreifi ${ }^{1}$, Debnath} Ghosal $^{3}$, Megan J Dobro ${ }^{4}$, Qing Yao ${ }^{1}$, Alasdair McDowall ${ }^{1}$, Ariane Briegel ${ }^{5}$, Morgan Beeby ${ }^{6}$, Yi-Wei Chang ${ }^{7}$, Carrie L. Shaffer ${ }^{2,8,9}$, Grant J. Jensen ${ }^{1,10,11}$

\author{
Affiliations \\ ${ }^{1}$ Division of Biology and Biological Engineering, California Institute of Technology, Pasadena, CA 91125, USA \\ ${ }^{2}$ University of Kentucky Department of Veterinary Science \\ ${ }^{3}$ Division of Medicine, Dentistry and Health Sciences, University of Melbourne, Parkville, Victoria, Australia \\ ${ }^{4}$ Hampshire College, Amherst, Massachusetts, USA \\ ${ }^{5}$ Leiden University, Sylvius Laboratories, Leiden, The Netherlands \\ ${ }^{6}$ Department of Life Sciences, Imperial College London, South Kensington Campus, London SW7 2AZ, UK \\ ${ }^{7}$ Department of Biochemistry and Biophysics, Perelman School of Medicine, University of Pennsylvania, \\ Philadelphia, PA 19104, USA \\ ${ }^{8}$ University of Kentucky Department of Microbiology, Immunology, and Molecular Genetics \\ ${ }^{9}$ University of Kentucky Department of Pharmaceutical Sciences \\ ${ }^{10}$ Department of Chemistry and Biochemistry, Brigham Young University, Provo, UT 84604, USA \\ ${ }^{11}$ Corresponding author: jensen@caltech.edu
}




\section{Abstract}

28 The flagellar type III secretion system (fT3SS) is a suite of membrane-embedded and cytoplasmic

29 proteins responsible for building the bacterial flagellar motility machinery. Homologous proteins

30 form the injectisome machinery bacteria use to deliver effector proteins into eukaryotic cells, and

31 other family members have recently been reported to be involved in the formation of membrane

32 nanotubes. Here we describe a novel, ubiquitous and evolutionarily widespread hat-shaped

33 structure embedded in the inner membrane of bacteria, of yet-unidentified function, that is related

34 to the fT3SS, adding to the already rich repertoire of this family of nanomachines. 
36 Type III secretion systems (T3SS) assemble bacterial machinery with diverse functions. In

37 addition to forming the flagellum and the injectisome, they have also been reported recently to be

38 involved in the formation of membrane tubes [1]. The flagellar type III secretion system (fT3SS)

39 consists of a cytoplasmic part containing an ATPase and an inner-membrane (IM)-embedded part

40 known as the core complex (fT3SScc). The fT3SScc consists of five proteins (FliP, FliQ, FliR,

41 FlhB and FlhA), with another protein, FliO, required for assembly but which does not form part

42 of the complex [2,3]. Initially, FliP forms a pentameric platform on which FliQ, FliR and FlhB

43 assemble to create a $\mathrm{FliP}_{5} \mathrm{FliQ}_{4} \mathrm{FliR}_{1} \mathrm{FlhB}_{1}$ subcomplex upon which an FlhA ring is built [4].

45 While using electron cryo-tomography (cryo-ET) to study the process of flagellar assembly in

46 Helicobacter pylori, we identified a periplasmic hat-shaped structure embedded in the inner

47 membrane (IM) of the cell (Fig. 1). The structure was abundant and, in contrast to the polar flagella

48 of this species, did not show any preferred spatial localization in the cell (e.g., not exclusively at

49 the cell pole). Carefully reexamining tens of thousands of cryotomograms of other,

50 phylogenetically-diverse bacterial species our lab has imaged over the past 15 years, we found that

51 this hat-like structure is widespread in diverse Gram-negative and Gram-positive bacteria (Fig. 2;

52 see also Supporting Figure S1). In many cases, we observed multiple hat-like structures (up to 10

53 in some cells) distributed around the cell (see Movie S1 for an example from an E. coli cell that

54 was partially lysed, enhancing visibility of periplasmic structures). Subtomogram averages of the

55 structure from different species revealed conserved characteristics: a hat-shaped part in the

56 periplasm and two cytoplasmic densities beneath (Fig. 2). In general, the periplasmic hat-like

57 portion had a diameter of $\sim 24-26 \mathrm{~nm}$ at its widest point at the outer surface of the IM. The

58 cytoplasmic densities were absent in the averages from three species: Pseudoalteromonas 
59 luteoviolacea, Hylemonella gracilis and Bacillus subtilis. The absence of these densities in $P$.

60 luteoviolacea and $B$. subtilis is likely due to the fact that these were lysed and not intact cells. We

61 also observed that the cytoplasmic density did not resolve into two distinct sections in all species.

62

63 We also identified the same structure in several $H$. pylori flagellar mutants: fliP*, $\Delta f l g S$ fliP*, $64 \Delta f l i M f l i P^{*}, \Delta f l i G f l i P^{*}, \Delta f l i O f l i P^{*}$, and $\Delta f l i Q f l i P^{*}$. The $H$. pylori fliP ${ }^{*}$ strain contains a naturally-

65 occurring point mutation that disrupts the function of FliP [5] and prevents the assembly of the

66 fT3SScc (manuscript in preparation). The other mutants remove additional fT3SScc proteins

$67(\Delta f l i O$ and $\Delta f l i Q)$, flagellar basal body proteins $(\Delta f l i M$ and $\Delta f l i G)$, or the tyrosine kinase

68 responsible for expression of the class II flagellar genes $(\Delta f \lg S)$ [6]. Curiously, in all of these

69 mutants the diameter of the hat-like density was reduced to only $20 \mathrm{~nm}$ (at its widest part) and

70 the two cytoplasmic densities were missing (or less well resolved) (Fig. 3 A-G). This difference

71 was not due to decreased resolution, since more particles were averaged than from wild-type cells

72 (see Materials and Methods). This observation suggested to us that the hat-like structure is related

73 to the fT3SScc. Indeed the general shape is reminiscent of the MS-ring of the flagellar motor, and

74 we observed the disappearance of two similar cytoplasmic densities in the motor (corresponding

75 to $F l h A_{C}$ ) in the same mutants while studying flagellar assembly (manuscript in preparation). The

76 reduced width of the hat-like structure in $f l i P^{*}$ cells is also reminiscent of the reduced width of

77 flagellar complexes in the absence of the fT3SScc [7].

78

79 To explore this relationship, we examined Campylobacter jejuni mutants of other fTSScc proteins.

80 These included mutants of the C-terminal domains of FlhA $(\Delta f l h A c)$ and FlhB $(\Delta f l h B c)[8]$. In

$81 \Delta f l h A c$ cells, compared to wild-type, the periplasmic hat-like part was again smaller in diameter 
82 and the two cytoplasmic densities disappeared (Fig. 3 I \& J). In contrast, the hat-like structure in

$83 \Delta f l h B c$ cells was indistinguishable from the wild-type complex both in diameter and the presence

84 of the associated cytoplasmic densities (Fig. $3 \mathrm{~K}$ ). This is not too surprising, since, unlike the large

85 pentameric FliP ring or the nonameric FlhA ring, FlhB is a small protein present in a monomeric

86 form in the fT3SScc. Although the absence of the C-terminus of FlhB renders the fT3SS non-

87 functional (no full flagella assemble in $\triangle f \operatorname{lhBc} C$. jejuni [8]), the fT3SScc can still assemble

88 (manuscript in preparation). To confirm the generality of the relationship between the fT3SScc

89 and the hat-like complex, we imaged an $f l h A$ mutant in $P$. aeruginosa $\left(f l h A^{*}\right.$, obtained from a

90 transposon insertion mutant library). Here also, the hat-like structure was smaller in size and lacked

91 clear cytoplasmic densities compared to wild-type (Fig. 3 L \& M).

93 Based on the apparent relationship between the fT3SScc and the hat-like structure, we

94 hypothesized that the novel complex is formed by the flagellar MS-ring protein, FliF, adopting a

95 different, more closed conformation than that seen in the fully-assembled flagellar motor. Hence,

96 we generated and imaged a $\Delta f l i F$ mutant in the $H$. pylori fli $P^{*}$ background. However, the hat-like

97 complex was still present in this mutant, indicating that it is not formed by FliF (Fig. $3 \mathrm{H}$ ). Thus

98 our observations suggest that while the cytoplasmic densities of the complex could be FlhAc, the

99 periplasmic density is not formed by FliF or any of the fT3SScc proteins. Of course, it is also

100 possible that $\mathrm{FlhA}_{\mathrm{C}}$ does not directly constitute the cytoplasmic densities, but rather that the

101 fT3SScc proteins are regulating the expression (or localization) of another protein(s) that does.

102

103 One possibility is that the hat-like structure we discovered here might represent an as-yet 104 unidentified scaffold that helps the fT3SScc assemble. If this structure is some sort of scaffold and 
105 the fT3SScc (or part of it) assembles within the hat-like portion and if the cytoplasmic densities 106 are FlhAc, this would explain the disappearance of the cytoplasmic densities and the smaller

107 diameter of the periplasmic portion in $f l i P^{*}$ and $f l h A$ mutants. The second possibility is that

108 fT3SScc proteins in some way regulate other proteins which themselves form the hat-like complex.

109 Such a regulatory role has been indicated previously for one of the fT3SScc proteins, FliO, which

110 is responsible for the optimal expression of other flagellar genes [9].

111

112 Whatever the function of this hat-like complex, it joins the already-rich repertoire of the (f)T3SS, 113 which has roles in flagellar motility, protein translocation and possibly membrane nanotube

114 formation. Whether the hat-like structure is connected to any of these functions or plays another,

115 yet-unidentified role remains to be elucidated. It is also possible that the apparently ancient 116 structure may have diverged to serve different functions in different species. 


\section{References:}

1. Bhattacharya S, Baidya AK, Pal RR, Mamou G, Gatt YE, Margalit H, et al. A Ubiquitous Platform for Bacterial Nanotube Biogenesis. Cell Reports. 2019;27: 334-342.e10. doi:10.1016/j.celrep.2019.02.055

2. Fabiani FD, Renault TT, Peters B, Dietsche T, Gálvez EJC, Guse A, et al. A flagellumspecific chaperone facilitates assembly of the core type III export apparatus of the bacterial flagellum. Stock A, editor. PLOS Biology. 2017;15: e2002267. doi:10.1371/journal.pbio.2002267

3. Fukumura T, Makino F, Dietsche T, Kinoshita M, Kato T, Wagner S, et al. Assembly and stoichiometry of the core structure of the bacterial flagellar type III export gate complex. Stock A, editor. PLOS Biology. 2017;15: e2002281. doi:10.1371/journal.pbio.2002281

4. Milne-Davies B, Wimmi S, Diepold A. Adaptivity and dynamics in type III secretion systems. Mol Microbiol. 2021;115: 395-411. doi:10.1111/mmi.14658

5. Chang Y-W, Shaffer CL, Rettberg LA, Ghosal D, Jensen GJ. In Vivo Structures of the Helicobacter pylori cag Type IV Secretion System. Cell Reports. 2018;23: 673-681. doi:10.1016/j.celrep.2018.03.085

6. Lertsethtakarn P, Ottemann KM, Hendrixson DR. Motility and Chemotaxis in Campylobacter and Helicobacter. Annual Review of Microbiology. 2011;65: 389-410. doi:10.1146/annurev-micro-090110-102908

7. Johnson S, Fong YH, Deme JC, Furlong EJ, Kuhlen L, Lea SM. Symmetry mismatch in the MS-ring of the bacterial flagellar rotor explains the structural coordination of secretion and rotation. Nature Microbiology. 2020 [cited 3 May 2020]. doi:10.1038/s41564-020-0703-3

8. Abrusci P, Vergara-Irigaray M, Johnson S, Beeby MD, Hendrixson DR, Roversi P, et al. Architecture of the major component of the type III secretion system export apparatus. Nature Structural \& Molecular Biology. 2013;20: 99-104. doi:10.1038/nsmb.2452

9. Tsang J, Hoover TR. Requirement of the Flagellar Protein Export Apparatus Component FliO for Optimal Expression of Flagellar Genes in Helicobacter pylori. Journal of Bacteriology. 2014;196: 2709-2717. doi:10.1128/JB.01332-13 
bioRxiv preprint doi: https://doi org/10.1101/2021.09.03 458937; this version posted September 4. 2021. The copyright holder for this preprint (which was not certified by peer review) is the author/funder, who has granted bioRxiv a license to display the preprint in perpetuity. It is made available under aCC-BY-NC-ND 4.0 International license.

\section{Figures}

\section{Figure 1}

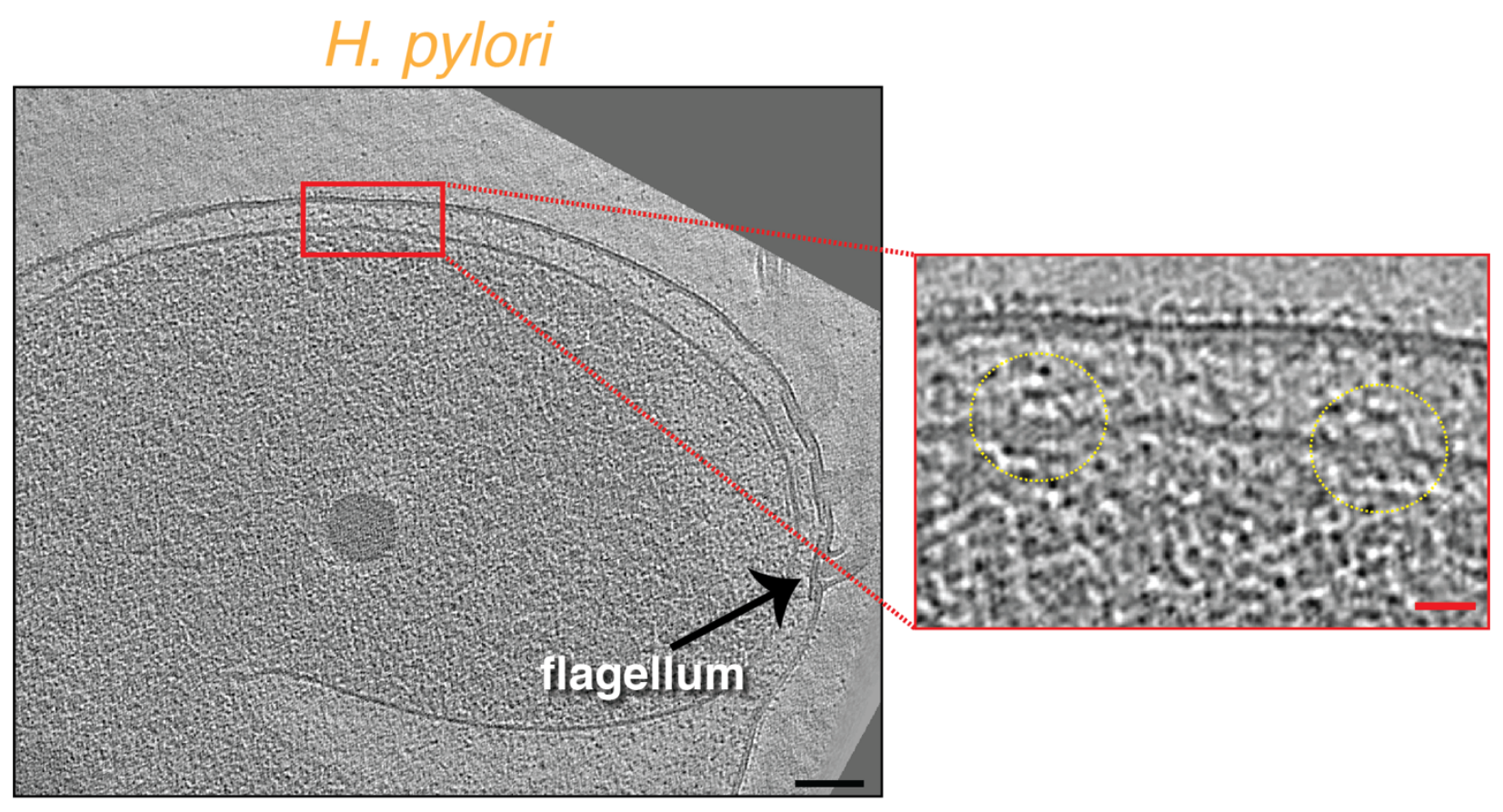

H. pylori fliP*
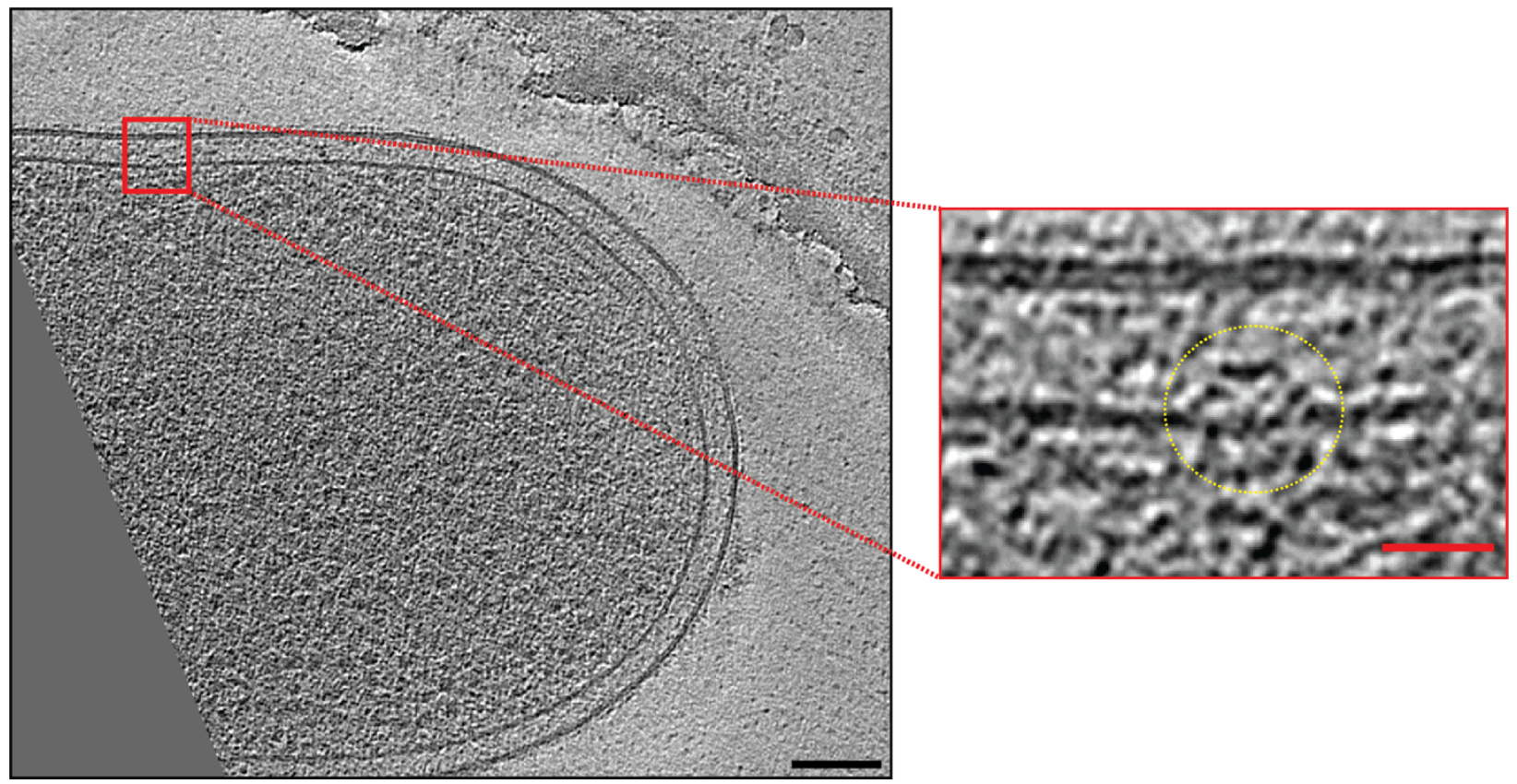
bioRxiv preprint doi: https://doi.org/10.1101/2021.09.03.458937: this version posted September 4, 2021. The copyright holder for this preprint (which was not certified by peer review) is the author/funder, who has granted bioRxiv a license to display the preprint in perpetuity. It is made available under aCC-BY-NC-ND 4.0 International license.

\section{Figure 2}

156

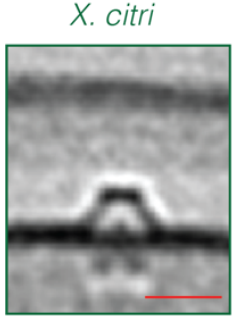

V. harveyi

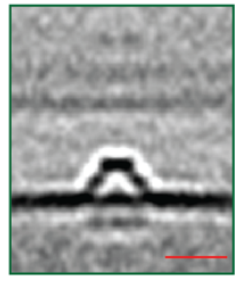

160

161

162

163

164

165

166

167

$P$. Iuteoviolacea

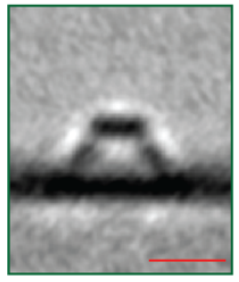

168

169

170

171

172

173

174

175
E. coli

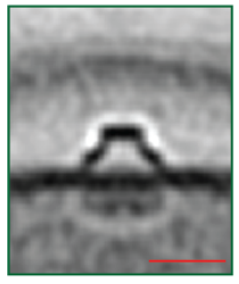

H. hepaticus

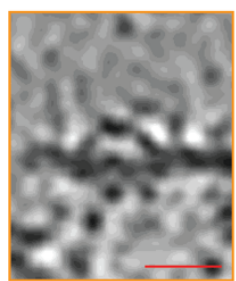

H. neptunium

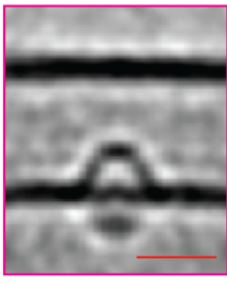

P. mirabilis

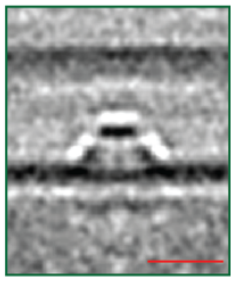

H. pylori

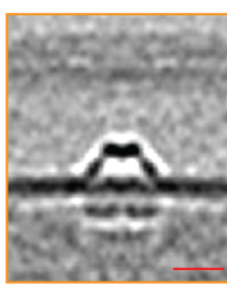

V. fischeri

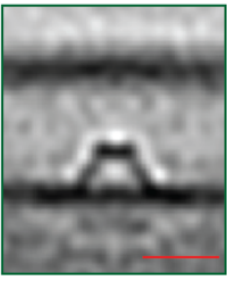

P. flexibilis

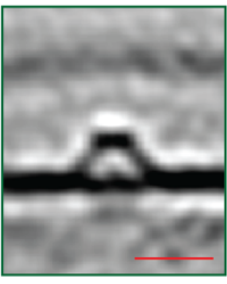

A. tumefaciens

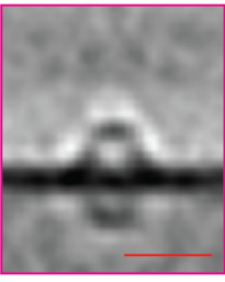

C.jejuni

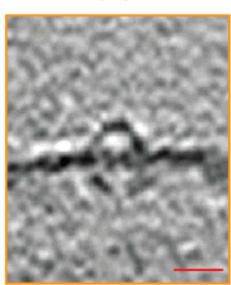

H. gracilis
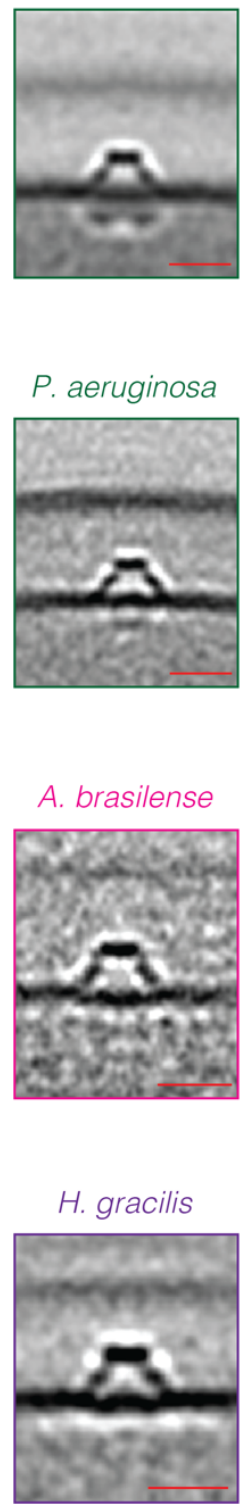

$P$. aeruginosa

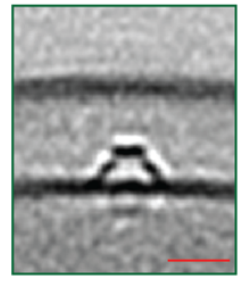

A. brasilense

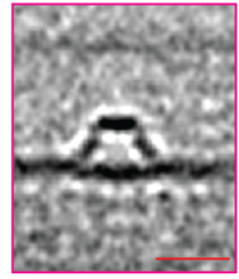

S. enterica

B. subtilis

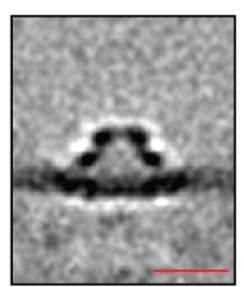

176 
bioRxiv preprint doi: https://doi.org/10.1101/2021.09.03.458937: this version posted September 4, 2021. The copyright holder for this preprint (which was not certified by peer review) is the author/funder, who has granted bioRxiv a license to display the preprint in perpetuity. It is made available under aCC-BY-NC-ND 4.0 International license.

\section{Figure 3}

H. pylori

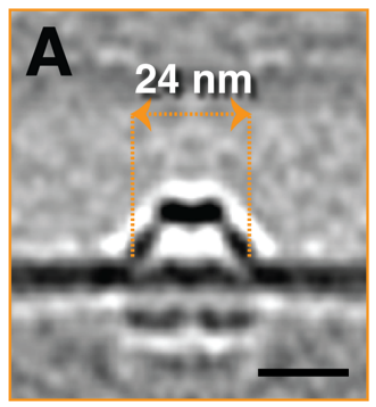

H. pylori $\Delta$ fliG fliP*

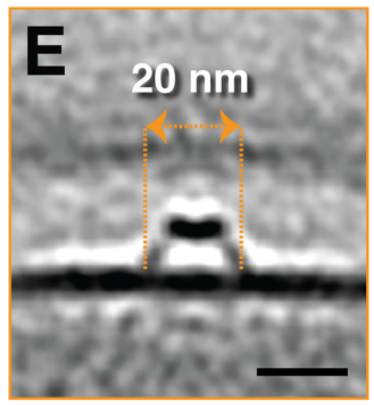

H. pylori fliP*

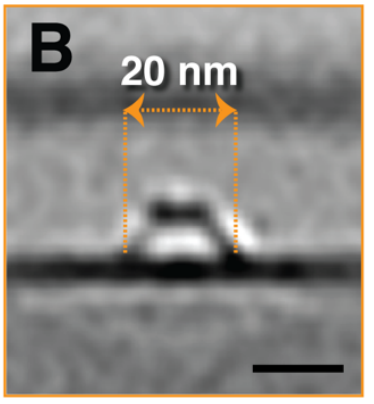

H. pylori $\triangle$ flim fliP*

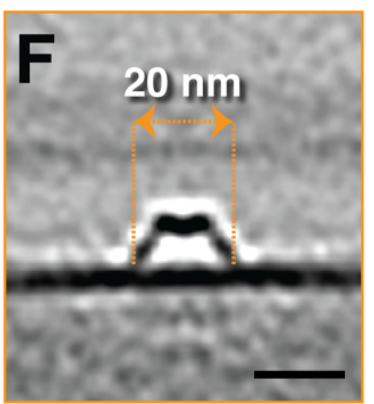

H. pylori $\triangle$ flgS fliP*

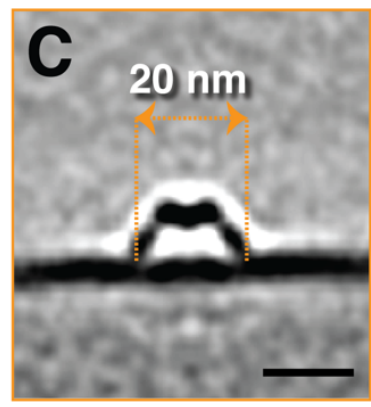

H. pylori $\triangle$ fliQ fliP*

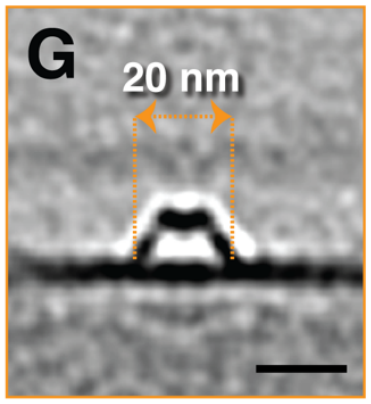

H. pylori $\triangle$ fliO fliP*

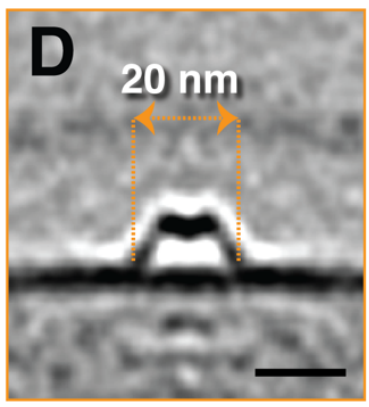

H. pylori $\triangle$ fliF fliP*

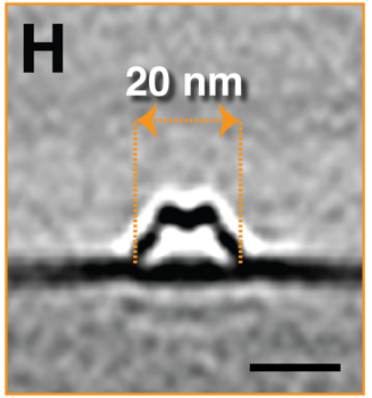

C. jejuni

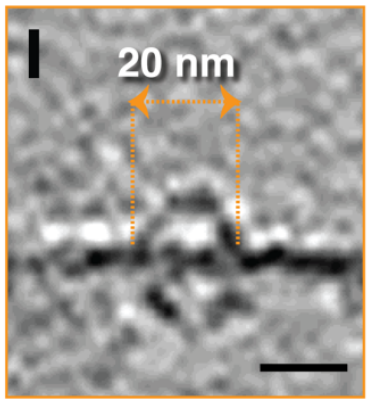

C. jejuni $\triangle f / h A_{C}$

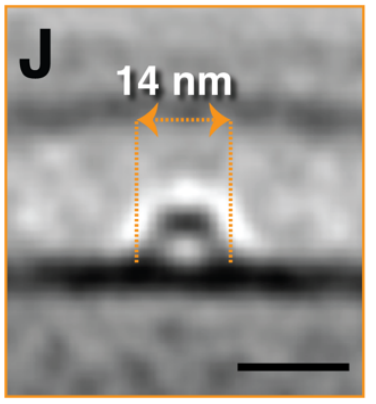

C. jejuni $\Delta f / h B_{C}$

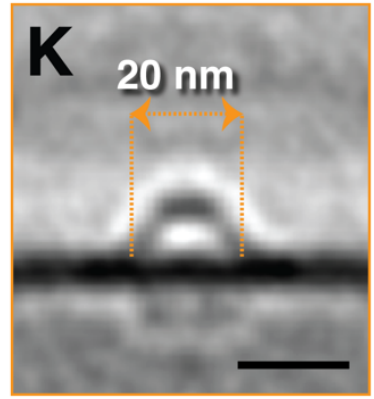

\section{$P$. aeruginosa}

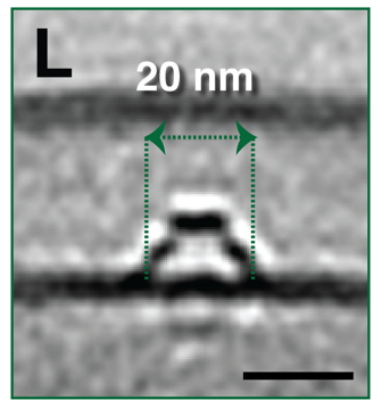

P. aeruginosa $\triangle \mathrm{flhA}$ *

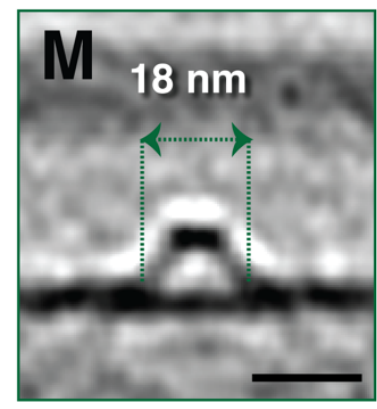


Figure legends:

Figure 1: Identification of a novel hat-like complex in $\boldsymbol{H}$. pylori. A \& B) slices through electron cryotomograms of $H$. pylori (A) or $H$. pylori fliP* (B) cells showing the presence of hat-like complexes (enlarged in red boxes). Black scale bars $100 \mathrm{~nm}$, red scale bars $25 \mathrm{~nm}$.

Figure 2: The hat-like complex is a widespread bacterial structure. A gallery of the hat-like complex in different bacterial species (Xanthomonas citri, Vibrio harveyi, V. fischeri, V. cholerae, Salmonella enterica, Pseudoalteromonas luteoviolacea, Proteus mirabilis, Pseudomonas flexibilis, P. aeruginosa, Legionella pneumophila, Escherichia coli, Hyphomonas neptunium, Agrobacterium tumefaciens, Azospirillum brasilense, Brucella abortus, Helicobacter hepaticus, Betaproteobacteria; and black, Bacilli. Scale bars are $20 \mathrm{~nm}$.

197 slices through sub-tomogram averages (except (I), where a single tomographic slice is shown) of

K) and P. aeruginosa (L \& M). Scale bars are $20 \mathrm{~nm}$. 
205 Mohammed Kaplan ${ }^{1}$, Catherine M Oikonomou ${ }^{1}$, Cecily R. Wood ${ }^{2}$, Georges Chreifi ${ }^{1}$, Debnath

206 Ghosal $^{3}$, Megan J Dobro ${ }^{4}$, Qing Yao ${ }^{1}$, Alasdair McDowall ${ }^{1}$, Ariane Briegel ${ }^{5}$, Morgan Beeby ${ }^{6}$, 
bioRxiv preprint doi: https://doi. org/10.1101/2021.09.03.458937: this version posted September 4, 2021. The copyright holder for this preprint (which was not certified by peer review) is the author/funder, who has granted bioRxiv a license to display the preprint in perpetuity. It is made available under aCC-BY-NC-ND 4.0 International license.

\section{S. enterica}

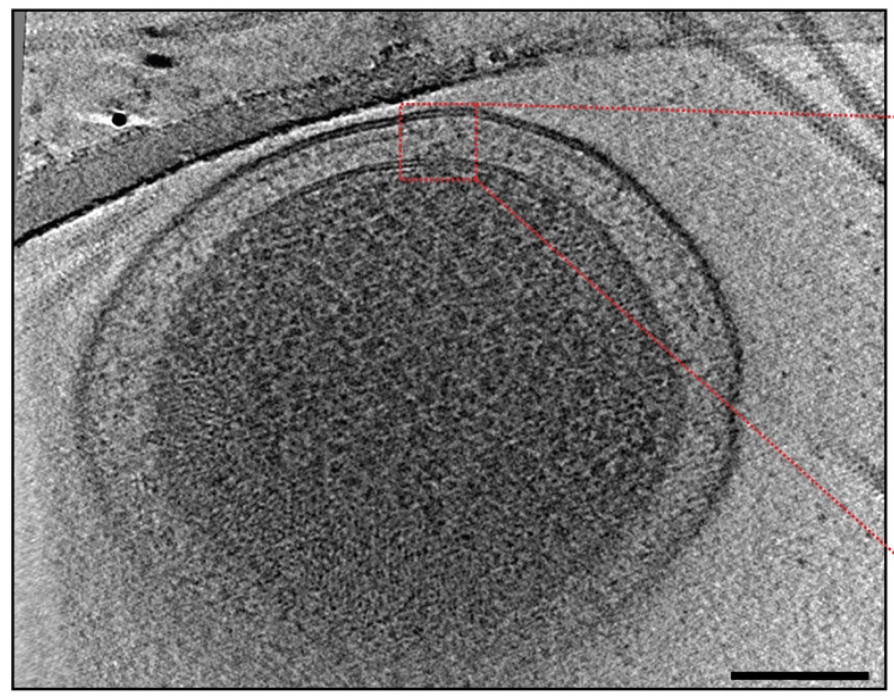

\section{E. coli}

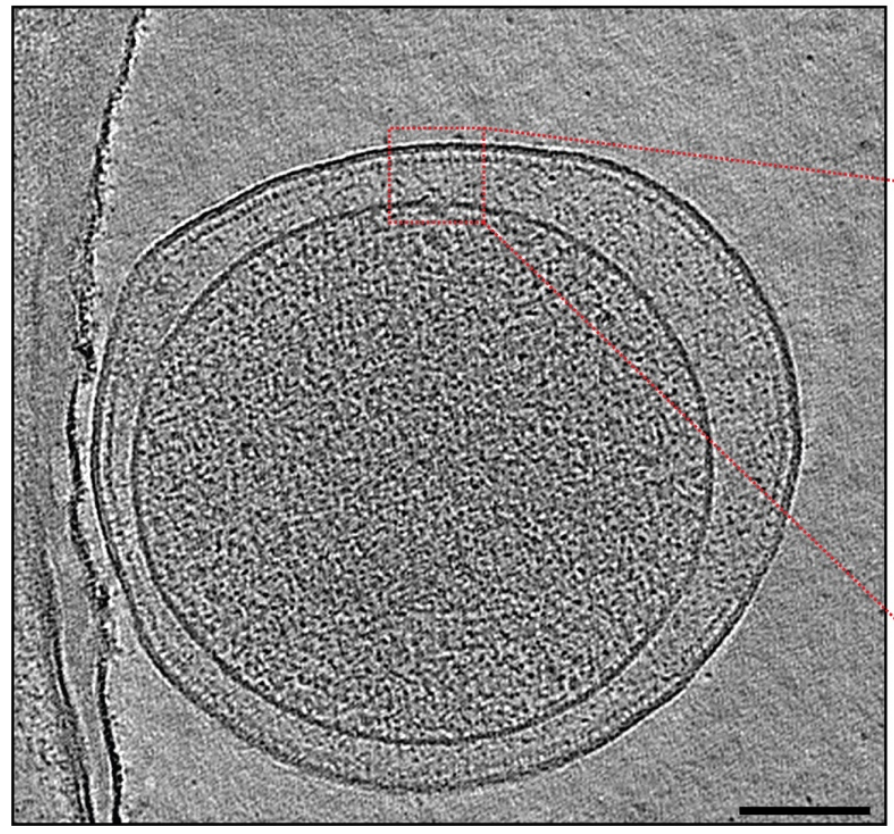

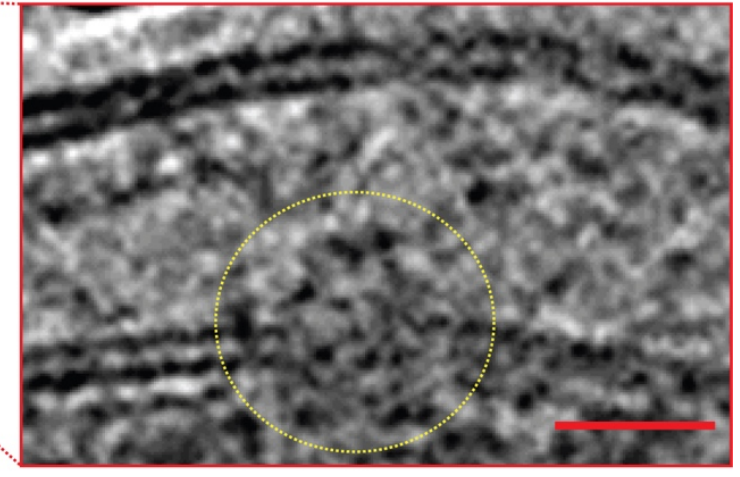

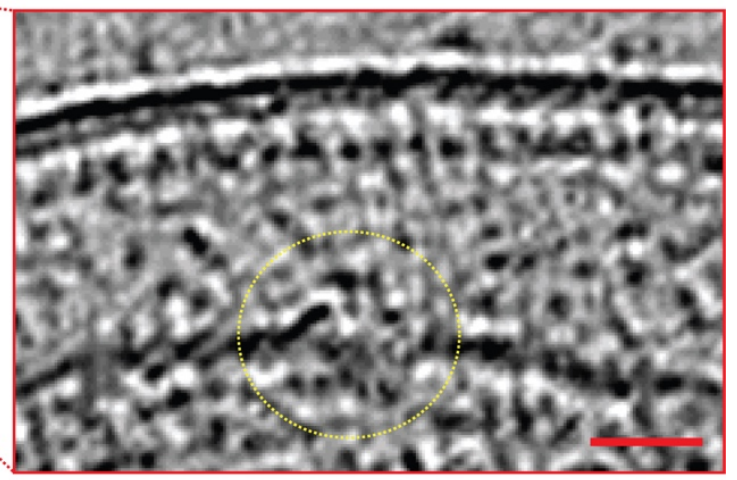


bioRxiv preprint doi: https://doi.org/10.1101/2021.09.03.458937; this version posted September 4, 2021. The copyright holder for this preprint

(which was not certified by peer review) is the author/funder, who has granted bioRxiv a license to display the preprint in perpetuity. It is made available under aCC-BY-NC-ND 4.0 International license.

V. cholerae

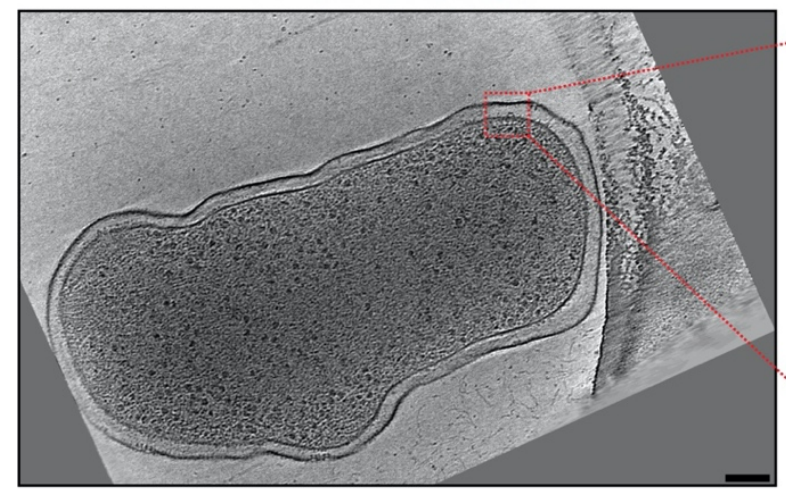

220

221

222

223

224

225

226

227

228

229

230

231

232

233

234

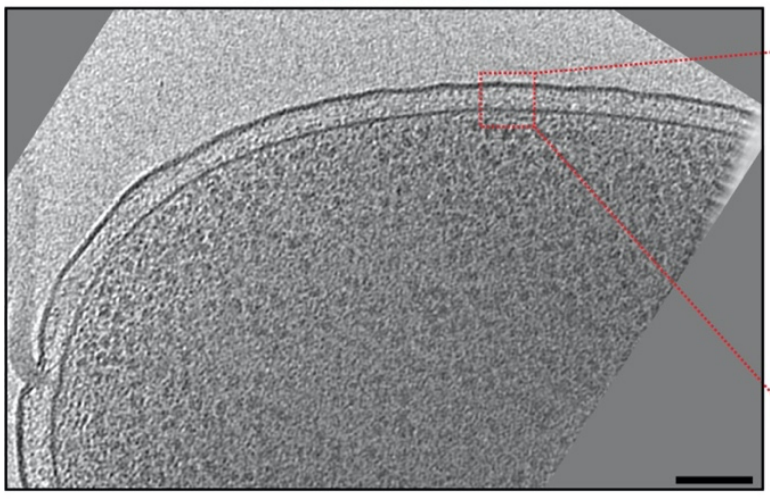

V. harveyi

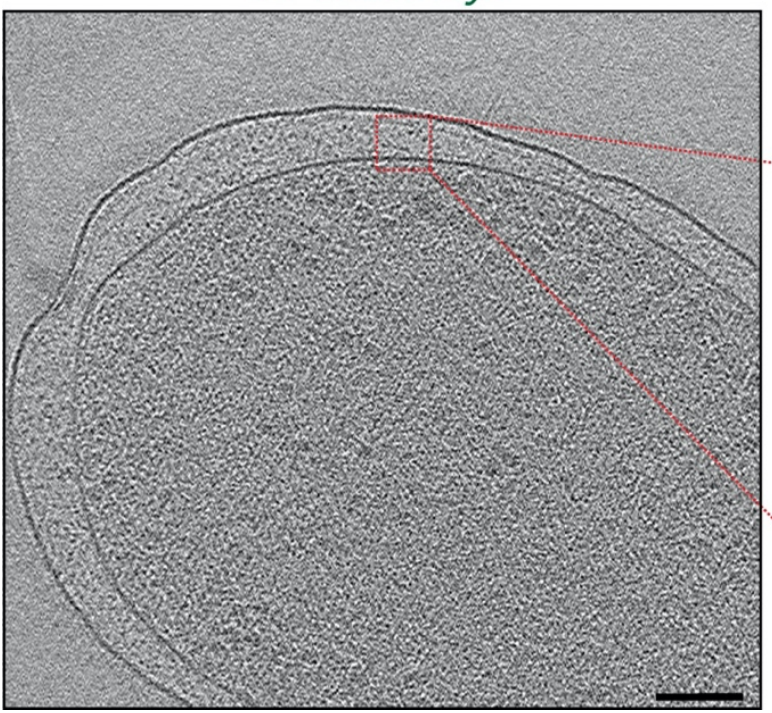

235

236
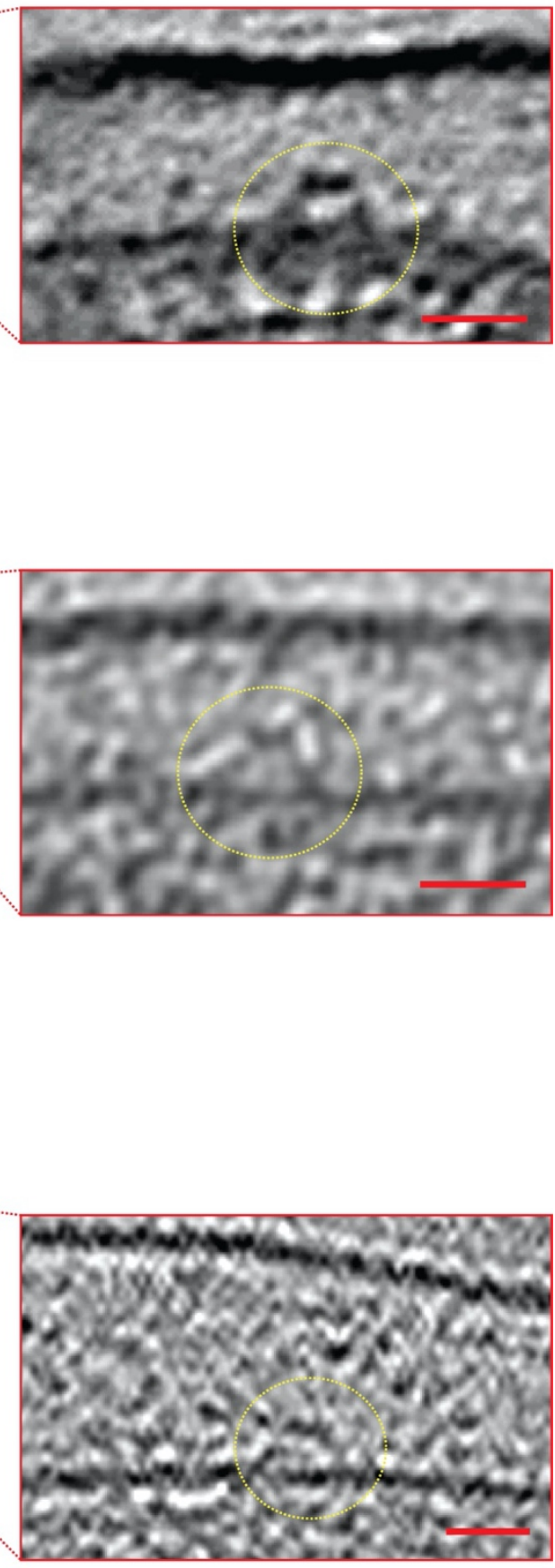
bioRxiv preprint doi: https://doi.org/10.1101/2021.09.03.458937; this version posted September 4, 2021. The copyright holder for this preprint (which was not certified by peer review) is the author/funder, who has granted bioRxiv a license to display the preprint in perpetuity. It is made available under aCC-BY-NC-ND 4.0 International license.
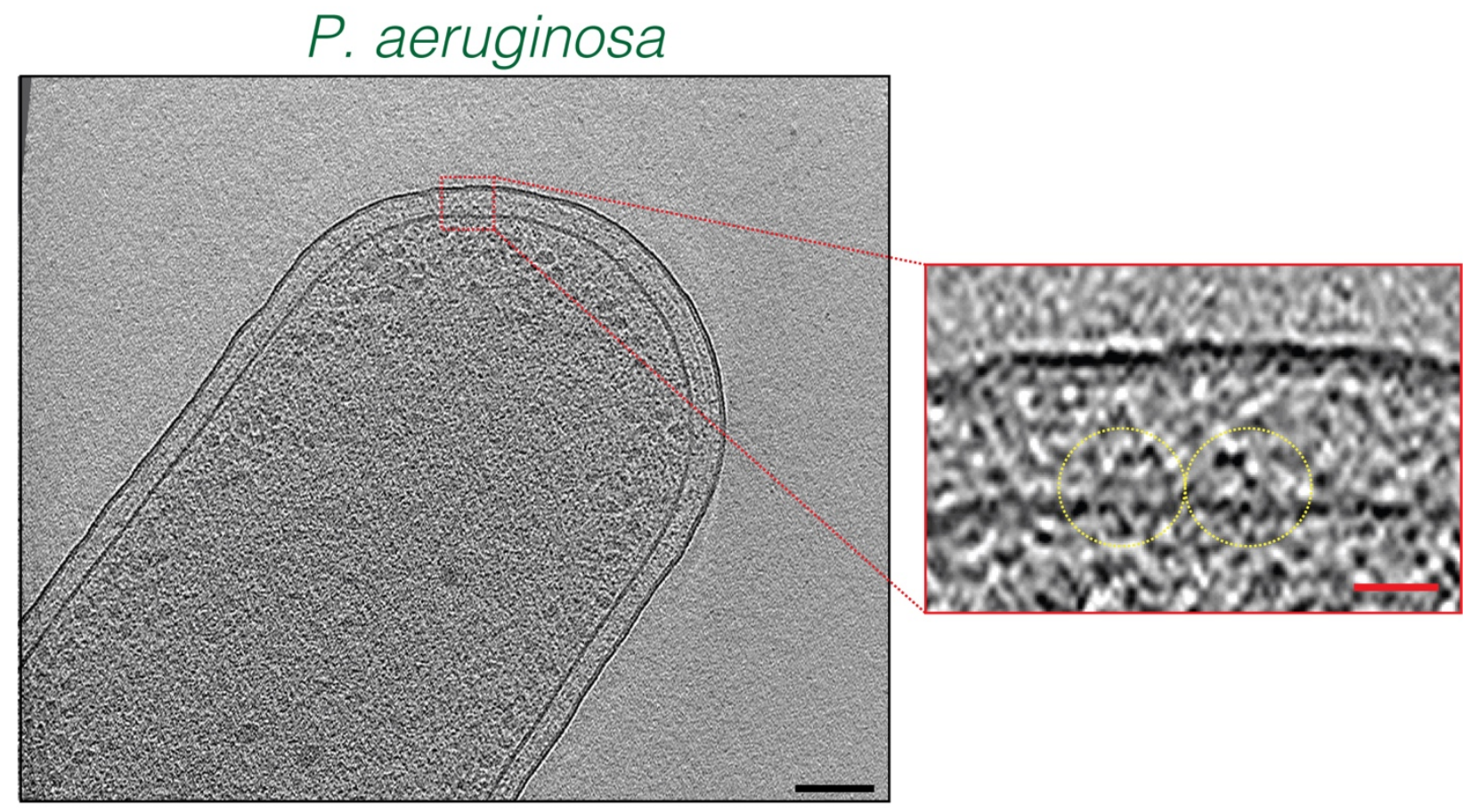

\section{L. pneumophila}
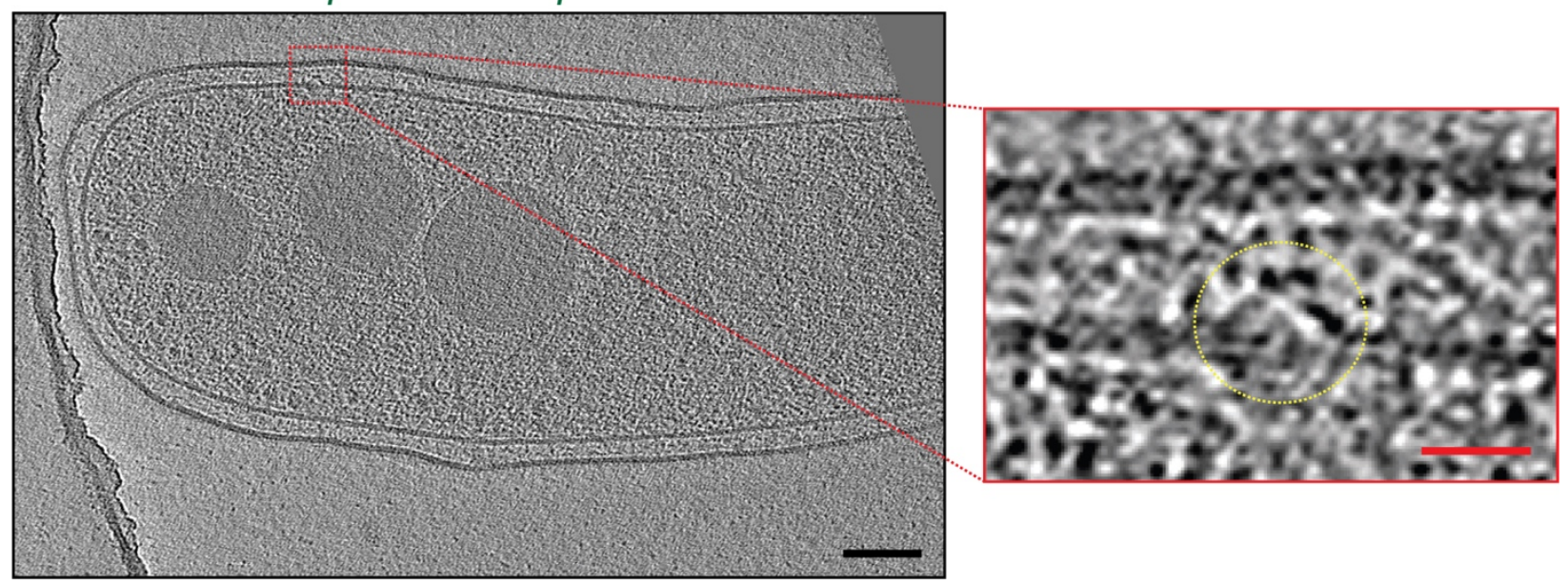
bioRxiv preprint doi: https://doi.org/10.1101/2021.09.03.458937· this version posted September 4, 2021. The copyright holder for this preprint

(which was not certified by peer review) is the author/funder, who has granted bioRxiv a license to display the preprint in perpetuity. It is made available under aCC-BY-NC-ND 4.0 International license.
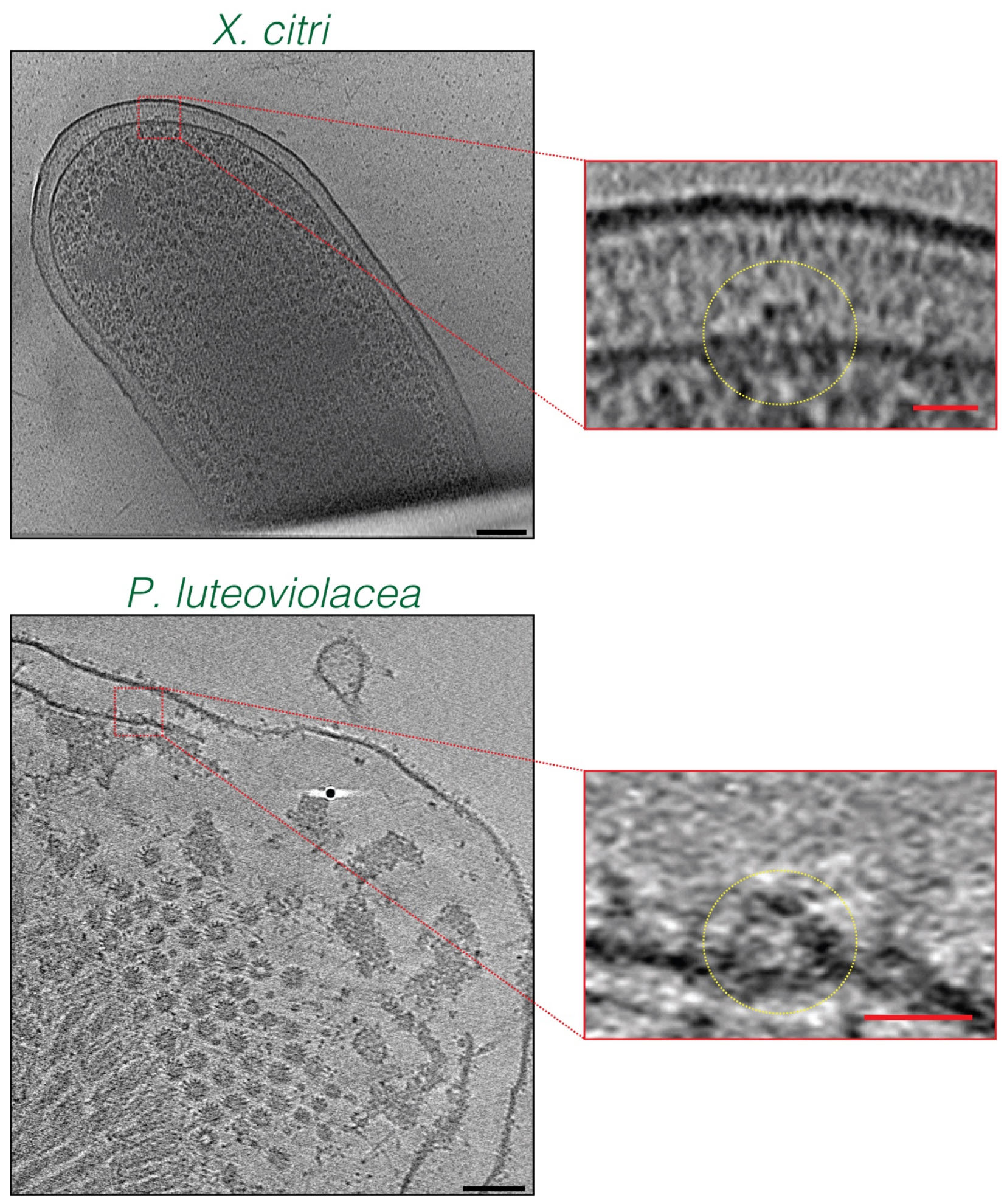
bioRxiv preprint doi: https://doi.org/10.1101/2021.09.03 458937- this version posted September 4, 2021. The copyright holder for this preprint (which was not certified by peer review) is the author/funder, who has granted bioRxiv a license to display the preprint in perpetuity. It is made available under aCC-BY-NC-ND 4.0 International license.

\section{P. flexibilis}

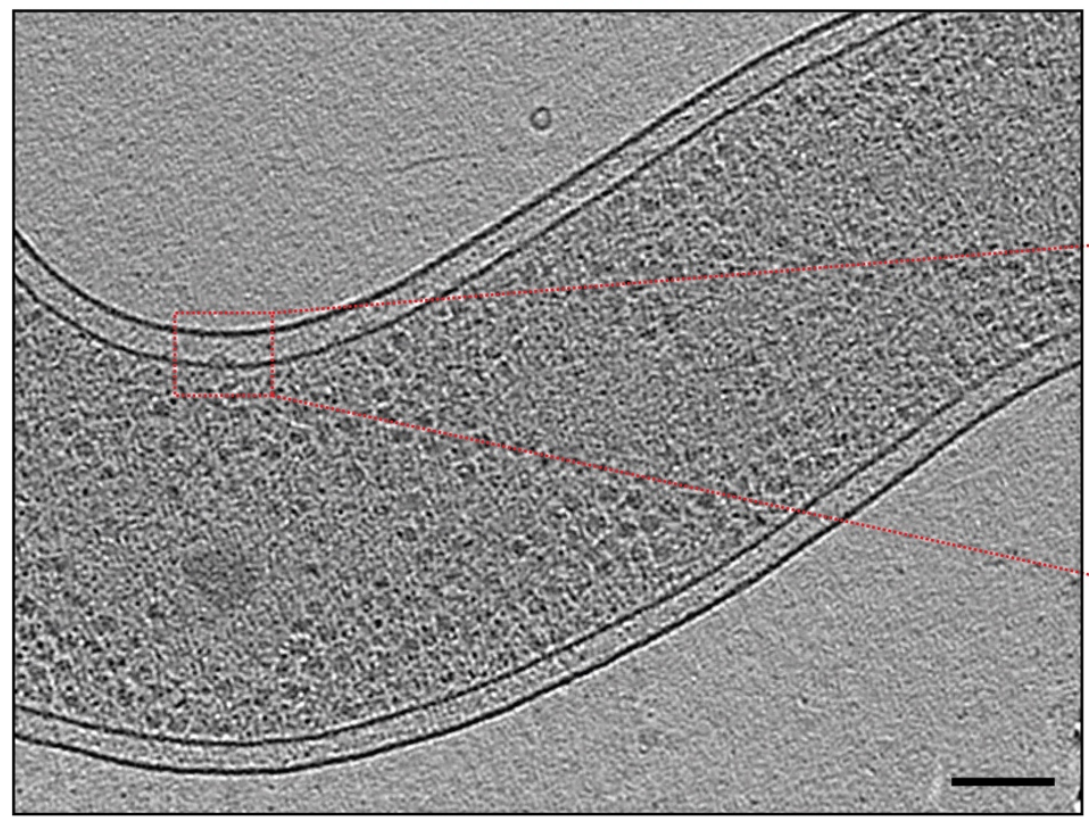

\section{P. mirabilis}

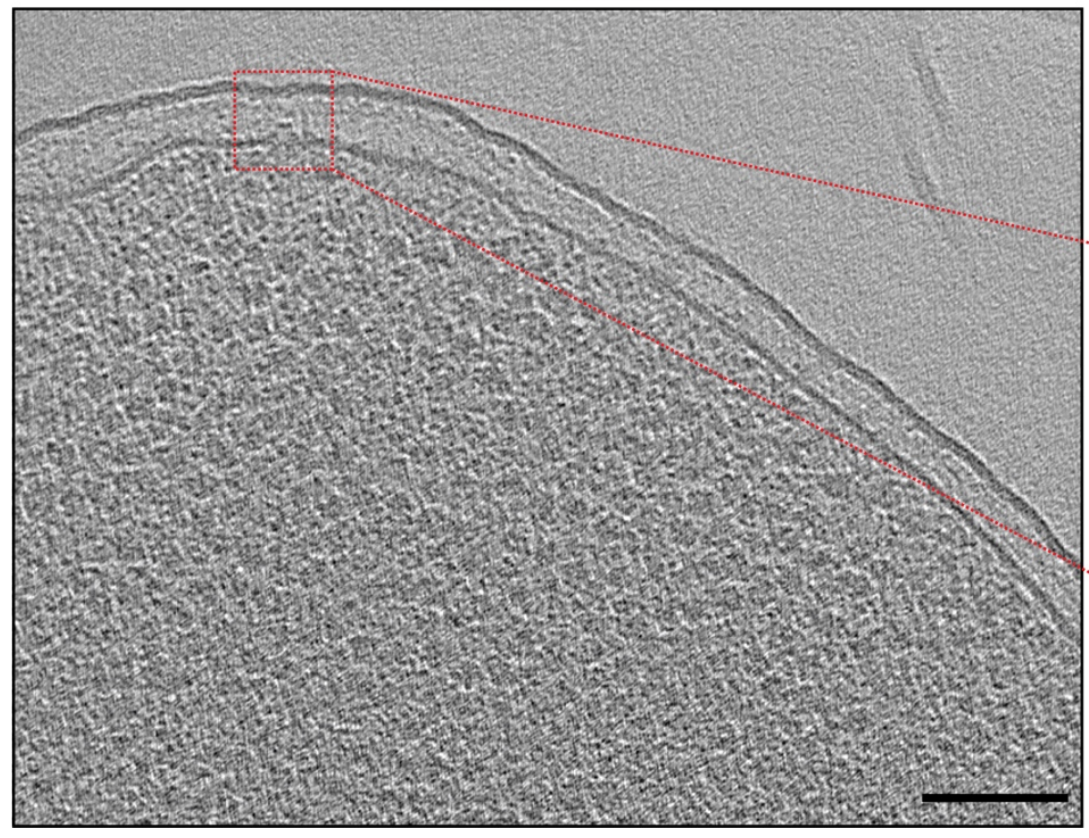

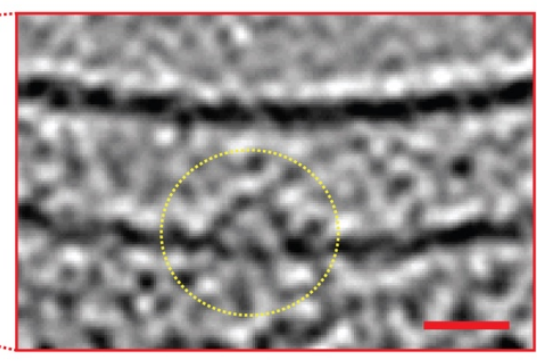

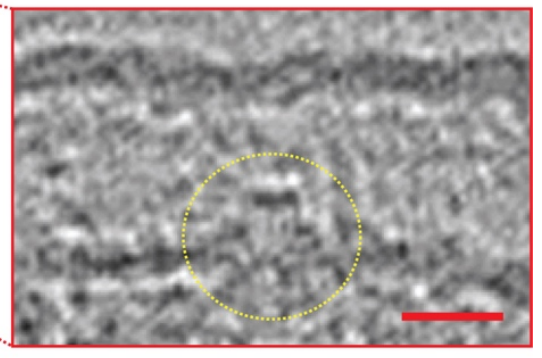


bioRxiv preprint doi: https://doi.org/10.1101/2021.09.03.458937; this version posted September 4, 2021. The copyright holder for this preprint

(which was not certified by peer review) is the author/funder, who has granted bioRxiv a license to display the preprint in perpetuity. It is made available under aCC-BY-NC-ND 4.0 International license.
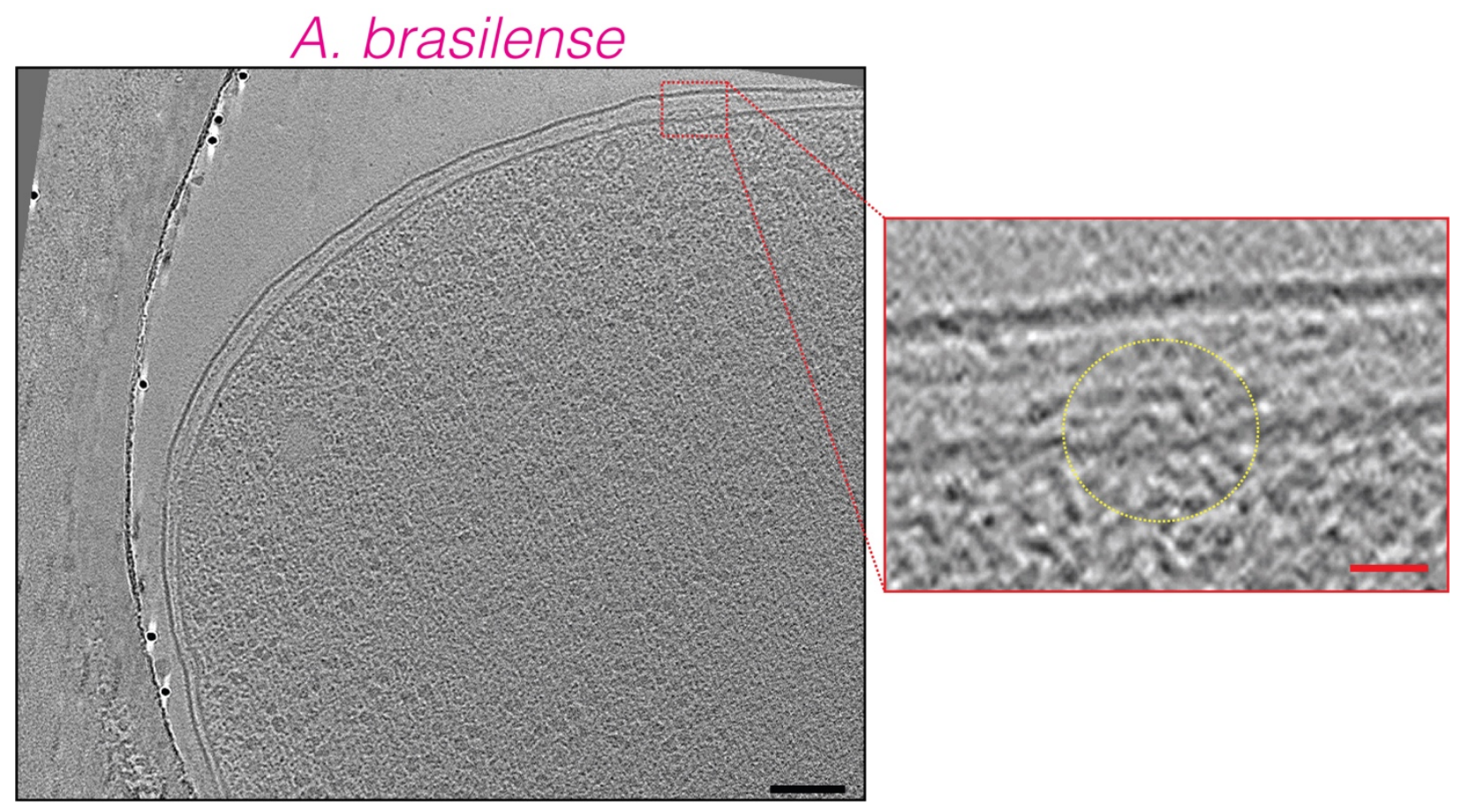

B. abortus
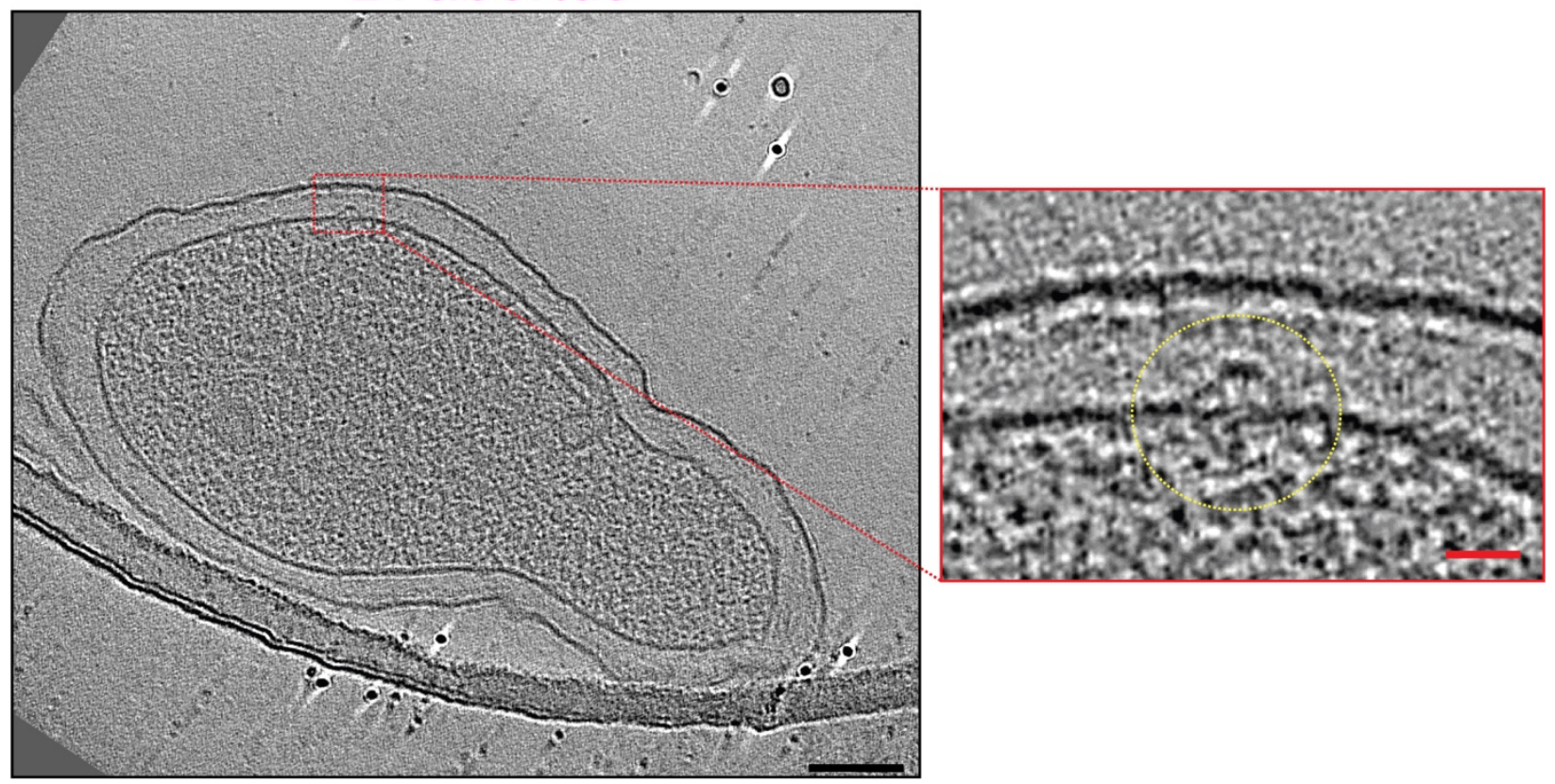
bioRxiv preprint doi: https://doi.org/10.1101/2021.09.03.458937: this version posted September 4, 2021. The copyright holder for this preprint (which was not certified by peer review) is the author/funder, who has granted bioRxiv a license to display the preprint in perpetuity. It is made available under aCC-BY-NC-ND 4.0 International license.
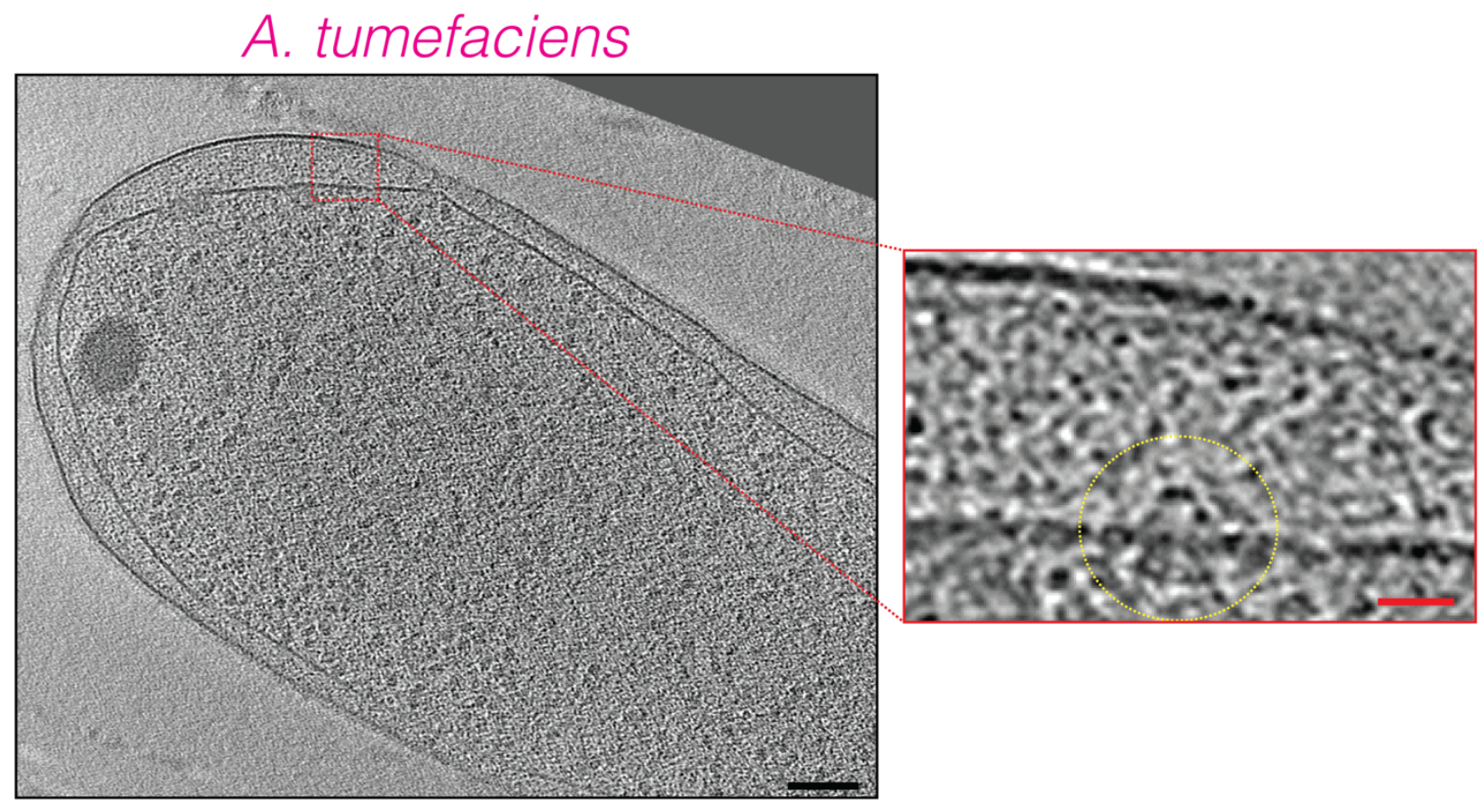

\section{H. neptunium}
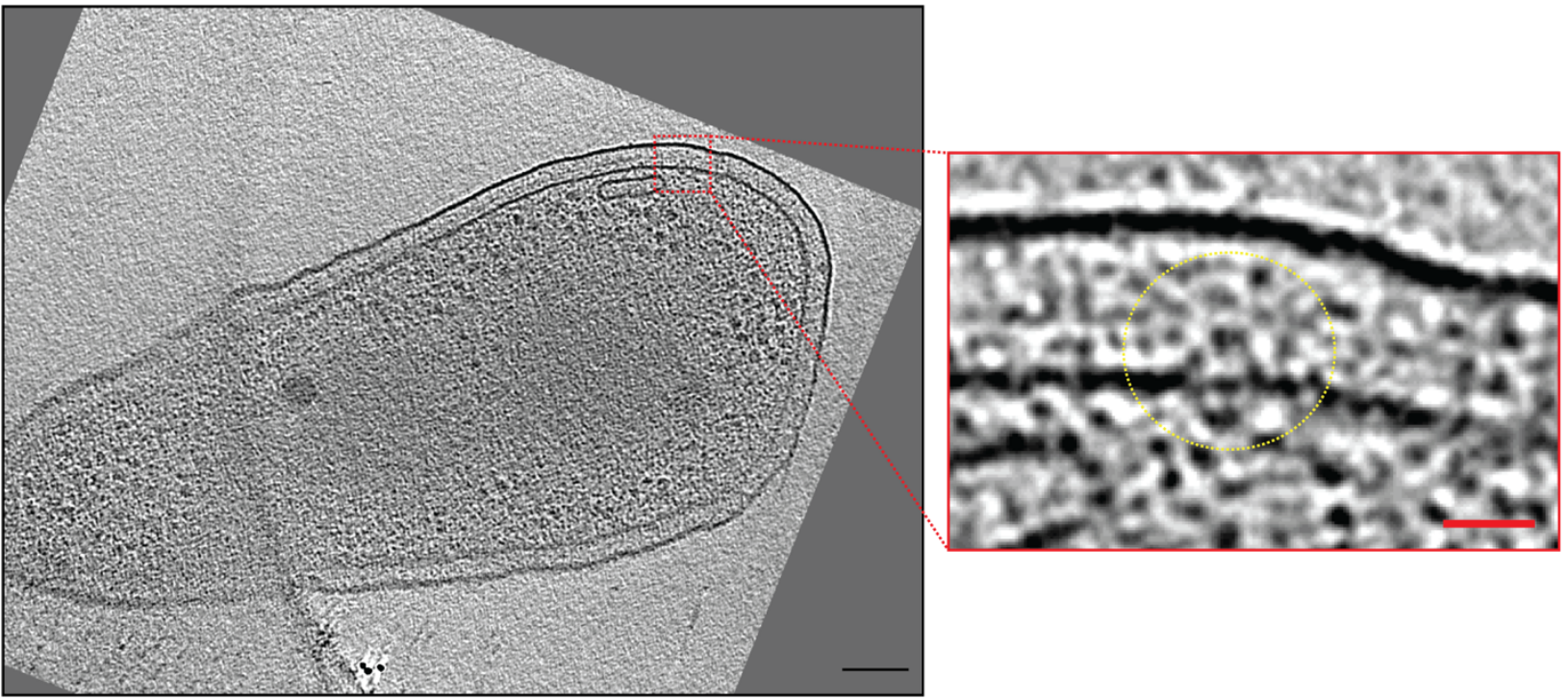

253 
bioRxiv preprint doi: https://doi.org/10.1101/2021.09.03.458937; this version posted September 4, 2021. The copyright holder for this preprint (which was not certified by peer review) is the author/funder, who has granted bioRxiv a license to display the preprint in perpetuity. It is made available under aCC-BY-NC-ND 4.0 International license.
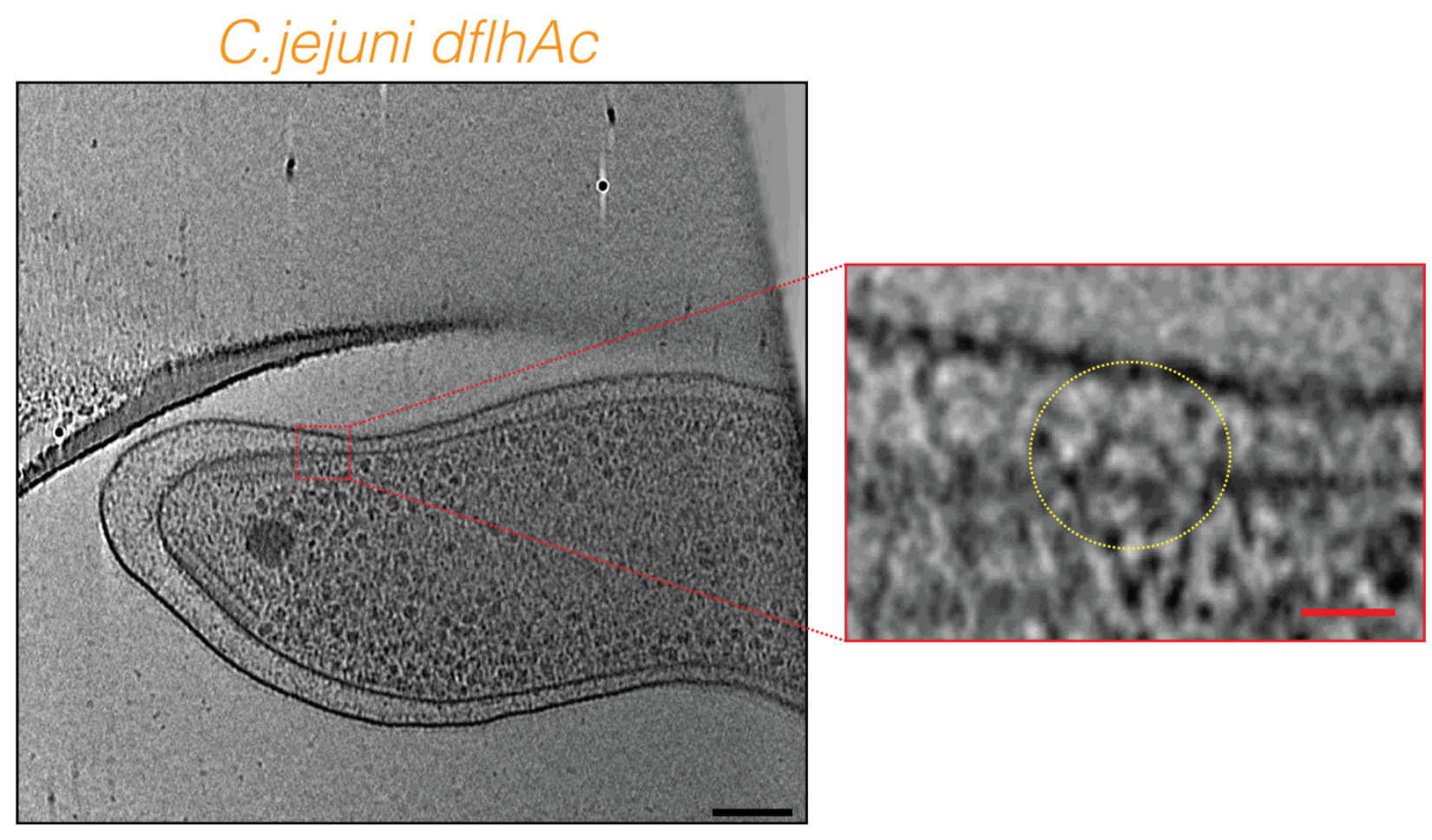

\section{C.jejuni dflhBc}
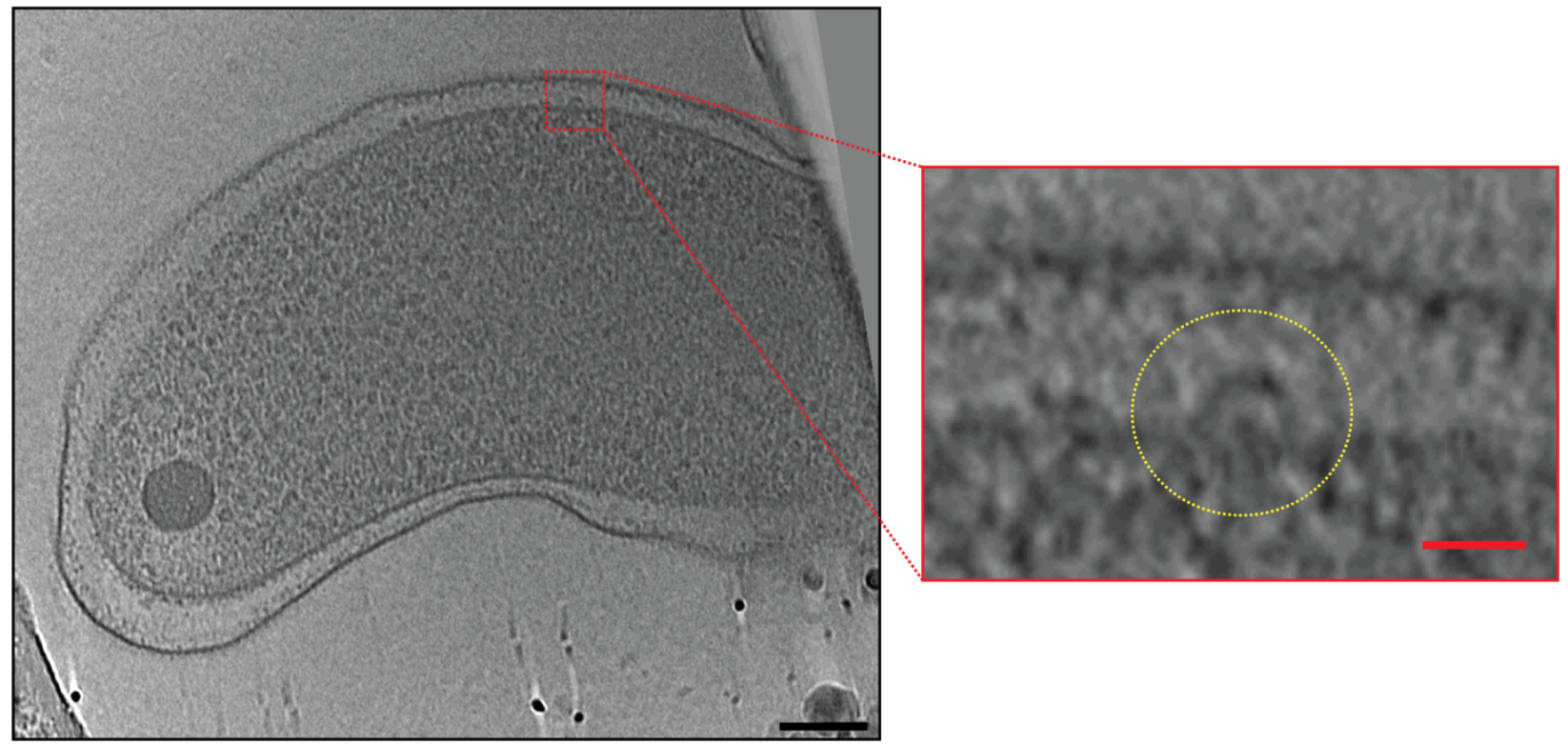
bioRxiv preprint doi: https://doi.org/10.1101/2021.09.03.458937; this version posted September 4, 2021. The copyright holder for this preprint

(which was not certified by peer review) is the author/funder, who has granted bioRxiv a license to display the preprint in perpetuity. It is made available under aCC-BY-NC-ND 4.0 International license.
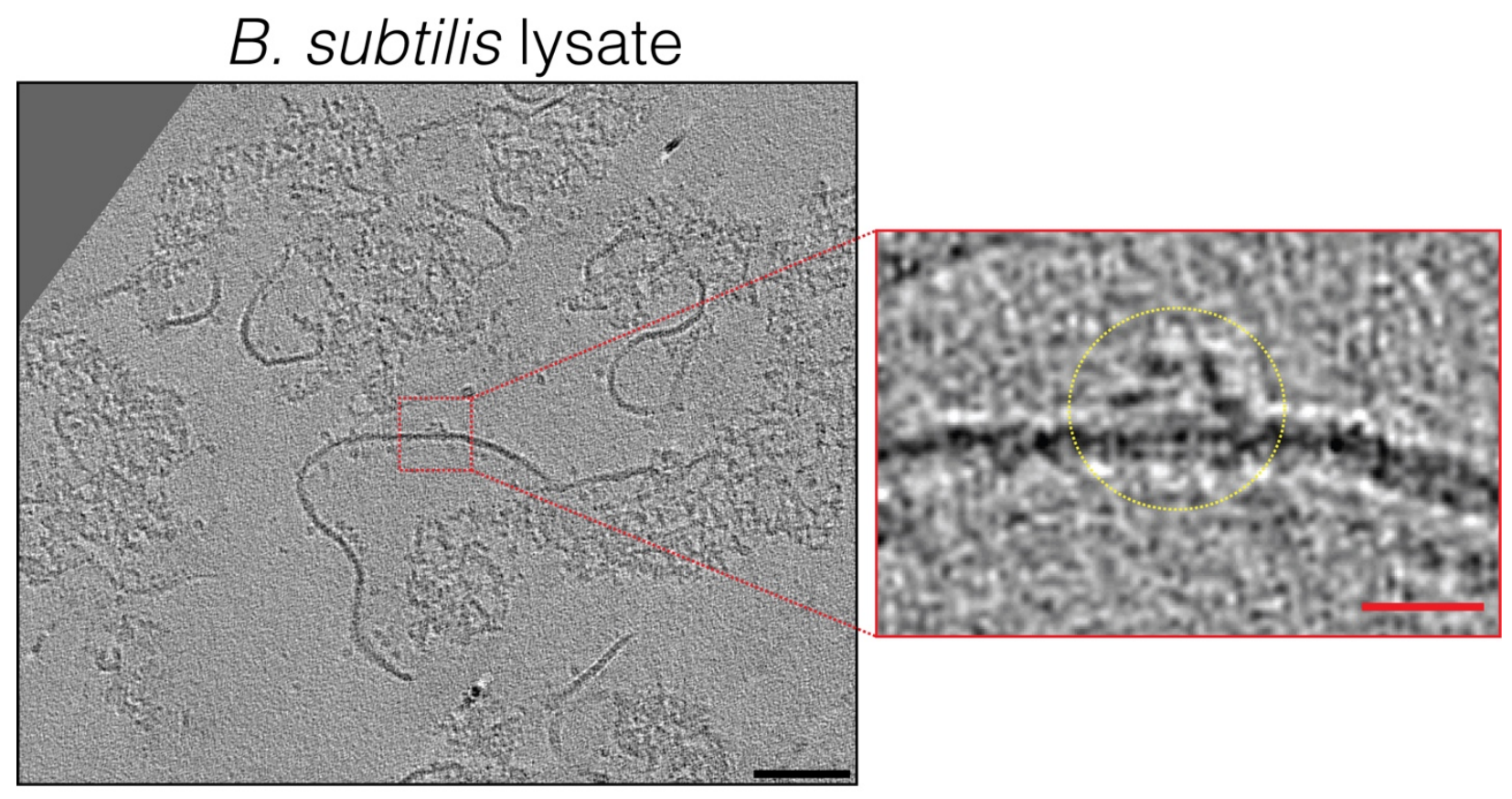

\section{H. gracilis}
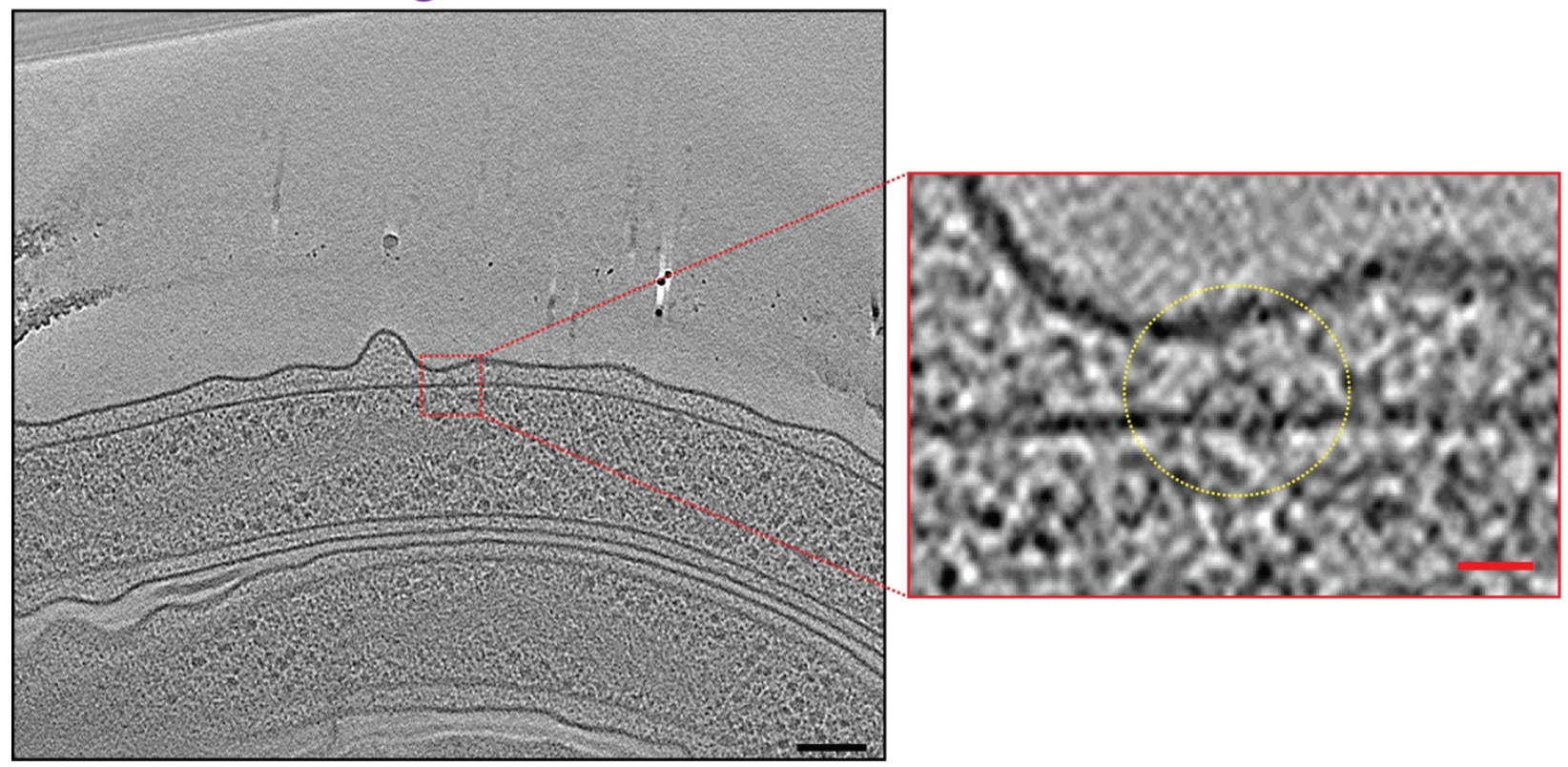

262 
266 Figure S1: Slices through electron cryotomograms of various bacterial species highlighting the

267 presence of hat-like complexes (dotted yellow circles in the enlarged views). Black scale bars 100

$268 \mathrm{~nm}$, red scale bars $20 \mathrm{~nm}$. 


\section{Movie S1:}

290 An electron cryotomogram of a partially-lysed E. coli cell highlighting the presence of multiple

291 hat-like complexes in the inner membrane (indicated by red circles). 


\section{Extended Materials and Methods:}

\section{Strains and growth conditions:}

314 E. coli cells were grown as described in ref. [1]. X. citri cells were grown in 2xTY medium for 14

315 hours to stationary phase. $V$. cholerae, $V$. harveyi and $V$. fischeri were grown as previously

316 described [2]. P. luteoviolacea were grown as described in ref. [3]. P. mirabilis were grown as

317 described in ref. [4]. $P$. aeruginosa were grown in LB medium at $37^{\circ} \mathrm{C}$ overnight. The $P$.

318 aeruginosa $\mathrm{flh}^{*}$ mutant was obtained from a transposon library (mutant number 3296 from the

319 non-redundant library http://pa14.mgh.harvard.edu/cgi-bin/pa14/downloads.cgi) from Dianne

320 Newman's lab at Caltech. L. pneumophila were grown as described in ref. [5]. S. enterica were

321 grown as in ref. [6]. P. flexibilis were grown in Lactose growth medium. H. neptunium were grown

322 to exponential phase in PYE medium. A. tumefaciens wild-type cells with plasmid-borne VirC1-

323 GFP translational fusion under control of the VirB promoter were grown in AB medium with 150-

$324300 \mathrm{ug} / \mathrm{ml}$ of kanamycin. A. brasilense and B. abortus were grown as described in ref. [7]. H.

325 hepaticus ATCC 51449 and $H$ gracilis were grown as described in ref. [1,8] C. jejuni and its

326 mutants were grown as described in ref. [6,9,10]. B. subtilis protoplasts were prepared using

327 lysozyme using a protocol based on ref. [11]. A motile revertant H. pylori 26695 isolate was

328 selected by serial passage in Brucella broth supplemented with 10\% heat inactivated fetal bovine

329 serum at $37^{\circ} \mathrm{C}, 5 \% \mathrm{CO}_{2}$ for 4 days until cultures reached an $\mathrm{OD}_{600} \sim 0.4$. Non-motile H. pylori

$330 \mathrm{fli}^{*}$ mutants were propagated on TSAII blood agar plates (BD Biosciences) at $37{ }^{\circ} \mathrm{C}, 5 \% \mathrm{CO}_{2}$ for

331 either 24 or $48 \mathrm{~h}$ prior to collection with a sterile cotton swab for grid preparation. Helicobacter

332 pylori mutants $\left(\triangle f l i M f l i P^{*}, \Delta f l i O f l i P^{*}, \Delta f l g S f l i P^{*}, \Delta f l i G f l i P^{*}, \Delta f l i Q f l i P^{*}\right)$ were grown directly

333 from glycerol stocks on sheep blood agar at $37{ }^{\circ} \mathrm{C}$ with $5 \% \mathrm{CO}_{2}$ for 48 hours. Then, the cells were

334 either collected from the plate using a cotton swab and dissolved in PBS and spun down and 
335 plunge-frozen directly, or the cells were spread on a new plate and allowed to grow for 24 hours

336 under the same conditions before plunge-freezing. No difference could be discerned between the

337 two samples by cryo-ET.

\section{H. pylori mutagenesis:}

340 Flagellar mutants were generated in the non-motile H. pylori 26695 background as previously

341 described [12]. Briefly, constructs were generated to replace the coding region of the gene of

342 interest with an in-frame, non-polar kanamycin resistance cassette. The target gene and

343 approximately 500 base pairs (bp) upstream and downstream of flanking regions were amplified

344 and cloned into pGEM T-Easy (Promega). This construct was used as a template for inverse PCR

345 to remove the majority of the target gene coding region and to introduce incompatible restriction

346 sites for directional cloning. A kanamycin resistance cassette driven by a promoter transcribed in

347 the same direction as the endogenous operon was cloned into the ligated inverse PCR plasmid. $H$.

348 pylori 26695 was transformed via natural competence, and single colonies resistant to kanamycin

$349(12.5 \mu \mathrm{g} / \mathrm{ml})$ were selected. PCR was used to verify that the kanamycin resistance cassette had 350 inserted into the target locus in the same orientation as operon transcription.

352 Electron cryo-tomography sample preparation and imaging:

353 Sample preparation for cryo-ET imaging was done as described in references [2,13,14]. Total

354 cumulative electron dose used for each tilt-series in each species was:

\begin{tabular}{|c|c|c|}
\hline Species name & Class & $\begin{array}{c}\text { Cumulative electron } \\
\text { dose }\left(\mathbf{e}^{-/} / \AA^{2}\right)\end{array}$ \\
\hline Xanthomonas citri & Gammaproteobacteria & 120 \\
\hline
\end{tabular}




\begin{tabular}{|c|c|c|}
\hline Vibrio harveyi & Gammaproteobacteria & 160 \\
\hline Vibrio fischeri & Gammaproteobacteria & 150 \\
\hline Vibrio cholerae & Gammaproteobacteria & 160 \\
\hline Salmonella enterica & Gammaproteobacteria & 200 \\
\hline $\begin{array}{c}\text { Pseudoalteromonas } \\
\text { luteoviolacea }\end{array}$ & Gammaproteobacteria & 180 \\
\hline Proteus mirabilis & Gammaproteobacteria & 160 \\
\hline Pseudomonas flexibilis & Gammaproteobacteria & 100 \\
\hline Pseudomonas fluorescens & Gammaproteobacteria & 200 \\
\hline Pseudomonas aeruginosa & Gammaproteobacteria & 170 \\
\hline Legionella pneumophila & Gammaproteobacteria & 100 \\
\hline Escherichia coli & Gammaproteobacteria & 130 \\
\hline Shewanella oneidensis MR1 & Gammaproteobacteria & 150 \\
\hline Hyphomonas neptunium & Alphaproteobacteria & 180 \\
\hline Agrobacterium tumefaciens & Alphaproteobacteria & 200 \\
\hline Azospirillum brasilense & Alphaproteobacteria & 200 \\
\hline Brucella abortus & Alphaproteobacteria & 160 \\
\hline Helicobacter hepaticus & Epsilonproteobacteria & 200 \\
\hline Helicobacter pylori & Epsilonproteobacteria & $120-130$ \\
\hline Campylobacter jejuni & Epsilonproteobacteria & 200 \\
\hline Hylemonella gracilis & Betaproteobacteria & 75 \\
\hline Bacillus subtilis & Bacilli & 160 \\
\hline
\end{tabular}




\section{Image processing and subtomogram averaging:}

357 Three-dimensional reconstructions of tilt-series were performed either automatically through the

358 RAPTOR pipeline used in the Jensen lab [15] or with the IMOD software package [16].

359 Subtomogram averaging was done using the PEET program [17] with a 2-fold symmetrization

360 applied along the particle $\mathrm{Y}$-axis. The number of particles that were averaged are:

\begin{tabular}{|c|c|}
\hline Figure & Number of particles \\
\hline Figure $2 X$. citri & 21 \\
\hline Figure $2 V$. harveyi & 46 \\
\hline Figure $2 V$. fischeri & 19 \\
\hline Figure 2 V. cholerae & 58 \\
\hline Figure 2 S. enterica & 38 \\
\hline Figure $2 P$. luteoviolacea & 50 \\
\hline Figure 2 P. mirabilis & 18 \\
\hline Figure 2 P. flexibilis & 23 \\
\hline Figure $2 P$. aeruginosa & 78 \\
\hline Figure 2 L. pneumophila & 149 \\
\hline Figure 2 E. coli & 31 \\
\hline Figure 2 H. neptunium & 23 \\
\hline Figure 2 A. tumefaciens & 29 \\
\hline Figure $2 \mathrm{~A}$. brasilense & 20 \\
\hline Figure 2 B. abortus & 41 \\
\hline Figure 2 H. pylori & 26 \\
\hline
\end{tabular}


bioRxiv preprint doi: https://doi.org/10.1101/2021.09.03.458937· this version posted September 4, 2021. The copyright holder for this preprint (which was not certified by peer review) is the author/funder, who has granted bioRxiv a license to display the preprint in perpetuity. It is made available under aCC-BY-NC-ND 4.0 International license.

\begin{tabular}{|c|c|}
\hline Figure $2 \mathrm{H}$. gracilis & 30 \\
\hline Figure 2 B. subtilis & 30 \\
\hline Figure $3 \mathrm{~A}$ & 26 \\
\hline Figure 3B & 118 \\
\hline Figure $3 \mathrm{C}$ & 60 \\
\hline Figure 3D & 29 \\
\hline Figure 3E & 27 \\
\hline Figure $3 \mathrm{~F}$ & 50 \\
\hline Figure $3 \mathrm{G}$ & 42 \\
\hline Figure $3 \mathrm{H}$ & 146 \\
\hline Figure 3J & 36 \\
\hline Figure $3 \mathrm{~K}$ & 37 \\
\hline Figure 3L & 78 \\
\hline Figure $3 \mathrm{M}$ & 17 \\
\hline
\end{tabular}




\section{Supplemental References:}

365

1. Chen S, Beeby M, Murphy GE, Leadbetter JR, Hendrixson DR, Briegel A, et al. Structural diversity of bacterial flagellar motors: Structural diversity of bacterial flagellar motors. The EMBO Journal. 2011;30: 2972-2981. doi:10.1038/emboj.2011.186

2. Kaplan M, Sweredoski MJ, Rodrigues JPGLM, Tocheva El, Chang Y-W, Ortega DR, et al. Bacterial flagellar motor PL-ring disassembly subcomplexes are widespread and ancient. Proceedings of the National Academy of Sciences. 2020; 201916935. doi:10.1073/pnas.1916935117

3. Shikuma NJ, Pilhofer M, Weiss GL, Hadfield MG, Jensen GJ, Newman DK. Marine Tubeworm Metamorphosis Induced by Arrays of Bacterial Phage Tail-Like Structures. Science. 2014;343: 529-533. doi:10.1126/science.1246794

4. Yao Q, Jewett Al, Chang Y, Oikonomou CM, Beeby M, lancu CV, et al. Short FtsZ filaments can drive asymmetric cell envelope constriction at the onset of bacterial cytokinesis. The EMBO Journal. 2017;36: 1577-1589. doi:10.15252/embj.201696235

5. Ghosal D, Kim KW, Zheng H, Kaplan M, Truchan HK, Lopez AE, et al. In vivo structure of the Legionella type II secretion system by electron cryotomography. Nature Microbiology. 2019 [cited 22 Nov 2019]. doi:10.1038/s41564-019-0603-6

6. Beeby M, Ribardo DA, Brennan CA, Ruby EG, Jensen GJ, Hendrixson DR. Diverse high-torque bacterial flagellar motors assemble wider stator rings using a conserved protein scaffold. Proceedings of the National Academy of Sciences. 2016;113: E1917-E1926. doi:10.1073/pnas.1518952113

7. Dobro MJ, Oikonomou CM, Piper A, Cohen J, Guo K, Jensen T, et al. Uncharacterized Bacterial Structures Revealed by Electron Cryotomography. Silhavy TJ, editor. Journal of Bacteriology. 2017;199. doi:10.1128/JB.00100-17

8. Briegel A, Ortega DR, Tocheva El, Wuichet K, Li Z, Chen S, et al. Universal architecture of bacterial chemoreceptor arrays. Proceedings of the National Academy of Sciences. 2009;106: 17181-17186. doi:10.1073/pnas.0905181106

9. Abrusci P, Vergara-Irigaray M, Johnson S, Beeby MD, Hendrixson DR, Roversi P, et al. Architecture of the major component of the type III secretion system export apparatus. Nature Structural \& Molecular Biology. 2013;20: 99-104. doi:10.1038/nsmb.2452

10. Müller A, Beeby M, McDowall AW, Chow J, Jensen GJ, Clemons WM. Ultrastructure and complex polar architecture of the human pathogen Campylobacter jejuni. MicrobiologyOpen. 2014;3: 702-710. doi:10.1002/mbo3.200 
11. DeCastro-Costa MR, Landman OE. Inhibitory protein controls the reversion of protoplasts and L forms of Bacillus subtilis to the walled state. J Bacteriol. 1977;129: 678-689. doi:10.1128/JB.129.2.678-689.1977

12. Shaffer CL, Gaddy JA, Loh JT, Johnson EM, Hill S, Hennig EE, et al. Helicobacter pylori Exploits a Unique Repertoire of Type IV Secretion System Components for Pilus Assembly at the Bacteria-Host Cell Interface. Salama N, editor. PLoS Pathogens. 2011;7: e1002237. doi:10.1371/journal.ppat.1002237

13. Kaplan M, Subramanian P, Ghosal D, Oikonomou CM, Pirbadian S, Starwalt-Lee R, et al. In situ imaging of the bacterial flagellar motor disassembly and assembly processes. The EMBO Journal. 2019; e100957. doi:10.15252/embj.2018100957

14. Kaplan M, Ghosal D, Subramanian P, Oikonomou CM, Kjaer A, Pirbadian S, et al. The presence and absence of periplasmic rings in bacterial flagellar motors correlates with stator type. eLife. 2019;8. doi:10.7554/eLife.43487

15. Ding HJ, Oikonomou CM, Jensen GJ. The Caltech Tomography Database and Automatic Processing Pipeline. Journal of Structural Biology. 2015;192: 279-286. doi:10.1016/j.jsb.2015.06.016

16. Kremer JR, Mastronarde DN, McIntosh JR. Computer visualization of three-dimensional image data using IMOD. J Struct Biol. 1996;116: 71-76. doi:10.1006/jsbi.1996.0013

17. Nicastro D. The Molecular Architecture of Axonemes Revealed by Cryoelectron Tomography. Science. 2006;313: 944-948. doi:10.1126/science.1128618 


\section{Acknowledgements}

428 This project was funded by the NIH (grant R01 AI127401 to G.J.J., and P20 GM130456 and P30

429 GM110787 to C.L.S.) and a Baxter postdoctoral fellowship from Caltech to M.K. Cryo-ET work

430 was done in the Beckman Institute Resource Center for Transmission Electron Microscopy at the

431 California Institute of Technology. We are grateful to Prof. Marc Erhardt (Humboldt-Universität

432 zu Berlin) for critically reading an initial version of this work. We thank Prof. Elitza I. Tocheva

433 for collecting the A. tumefaciens data, Dr. Jian Shi for collecting the H. neptunium data, and Prof.

434 Martin Pilhofer for collecting the P. luteoviolacea data. 